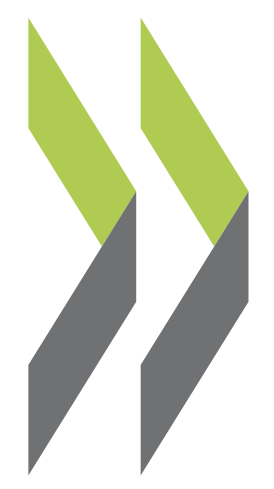

OECD Economics Department Working Papers No. 574

\section{Too little Destruction too little Creation: A} Schumpeterian Diagnosis of Barriers to Sustained Growth in Ukraine
Christian Gianella, William Tompson 
Organisation de Coopération et de Développement Economiques

Organisation for Economic Co-operation and Development

ECONOMICS DEPARTMENT

English text only

TOO LITTLE DESTRUCTION TOO LITTLE CREATION: A SCHUMPETERIAN DIAGNOSIS OF BARRIERS TO SUSTAINED GROWTH IN UKRAINE

ECONOMICS DEPARTMENT WORKING PAPERS No. 574

by

Christian Gianella and William Tompson

All OECD Economics Department Working Papers are available on the OECD Internet website at www.oecd.org/eco/working_papers 


\section{ABSTRACT/RÉSUMÉ}

\section{Too Little Destruction, Too Little Creation: A Schumpeterian Diagnosis of Barriers to Sustained Growth in Ukraine}

This paper examines problems of entry, exit and competition in Ukrainian product markets. It finds that Ukraine still has too little of all three, and that exit mechanisms, in particular, function poorly. Since impediments to entry and exit are largely the product of excessive and ill administered regulation, the paper also provides a systematic assessment of product-market regulation in Ukraine, using indicators developed by the OECD Economics Department. Finally, the paper presents the main findings of two empirical studies concerned with the potentially large benefits of opening up markets, via both increased competition and further privatisation, for productivity growth in Ukraine.

This paper relates to the 2007 Economic Survey of Ukraine (www.oecd.org/eco/studies/ukraine).

JEL Classification: D24, D43, H11, L1, L5, L9, O12, P23

Keywords: Ukraine; competition; product-market regulation; creative destruction; entry; exit; restructuring, privatisation.

\section{Une insuffisance de création-destruction: un diagnostic schumpétérien des freins à la croissance en Ukraine}

Cet article examine les questions de concurrence, d'entrée et de sortie des entreprises sur le marché des biens. Il montre que toutes trois demeurent insuffisantes en Ukraine, et que les mécanismes de sortie du marché, en particulier, fonctionnent de manière très imparfaite. Compte tenu du fait que les barrières à l'entrée et à la sortie sont largement le produit d'une réglementation excessive et mal appliquée, l'article donne une évaluation systématique du niveau de réglementation du marché des biens en Ukraine, en utilisant les indicateurs développés par le Département des affaires économiques. Enfin, l'article expose les principaux résultats de deux études empiriques évaluant les effets bénéfiques sur la croissance de la productivité de l'ouverture des marchés, d'une part par un accroissement de la concurrence et d'autre part par la poursuite des privatisations.

$\mathrm{Ce}$ document se rapporte à l'Etude économique de l'Ukraine 2007 (www.oecd.org/eco/etudes/ukraine).

Classification JEL: D24, D43, H11, L1, L5, L9, O12, P23

Mots clés: Ukraine, concurrence, réglementation des marchés des biens, destruction créatrice, entrée sur le marché, sortie du marché, restructuration, privatisation.

\section{Copyrights, OECD, 2007}

Application for permission to reproduce or translate all, or part of, this material should be made to: Head of Publications Service, OECD, 2 rue André-Pascal, 75775 Paris Cedex 16, France. 


\section{TABLE OF CONTENTS}

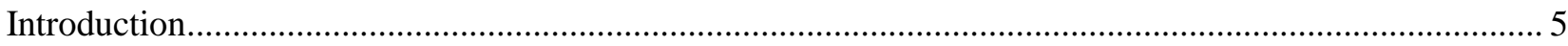

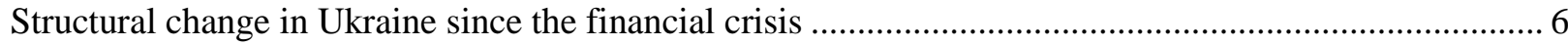

Increasingly intensive job reallocation has been productivity enhancing ........................................... 6

...but entry and particularly exit mechanisms still works poorly ....................................................... 8

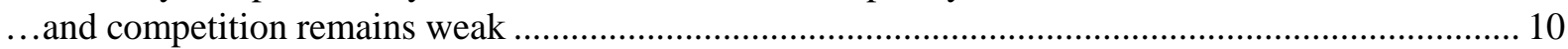

Competition policy has improved but much remains to be done ....................................................... 13

Reducing barriers to entry, exit and reallocation: the role of product-market reform............................ 14

The regulatory framework in Ukraine: a comparison with OECD countries ....................................... 15

Conditions for start-ups are easier, but barriers to entry for foreigners remain very high.................... 17

Overregulation impedes business growth and development............................................................... 18

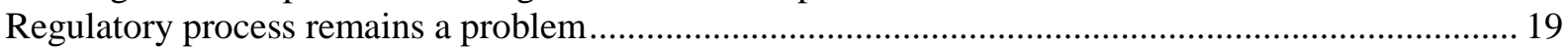

Excessive state ownership adds to the impediments to efficient exit .................................................. 20

Overall, barriers to exit may be even more significant than restrictions on entry ................................. 21

Implicit and explicit subsidies, though declining, persist on a large scale ............................................ 22

The potential benefits of enhanced competition and further privatisation .............................................. 23

Strengthening competition improves the performance of Ukrainian firms ……................................... 23

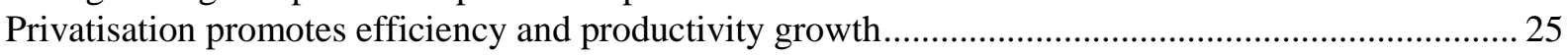

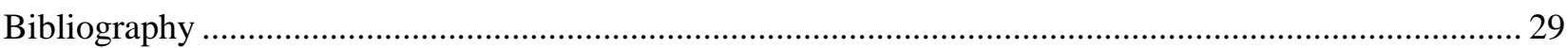

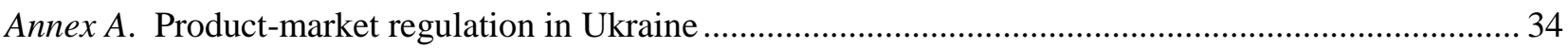

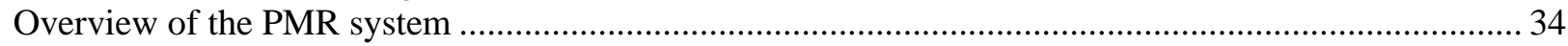

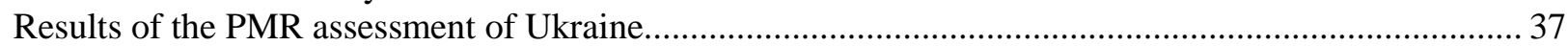

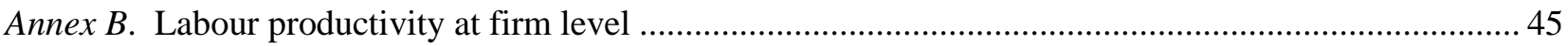

Annex $C$. Competition and productivity dynamics at the firm level ........................................................ 47

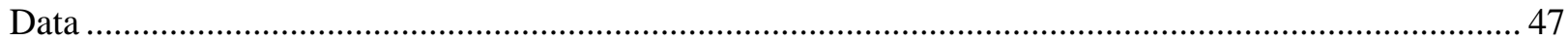

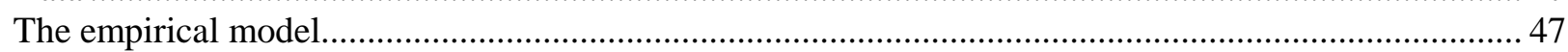

\section{Tables}

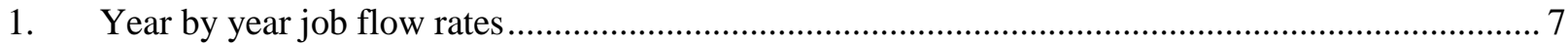

2. Correlation between labour productivity deviation and employment share change …................... 8

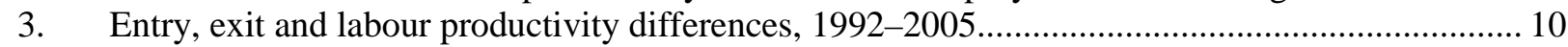

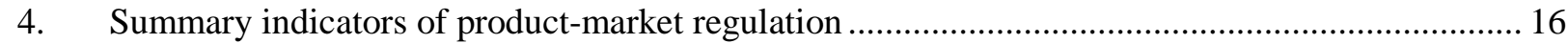

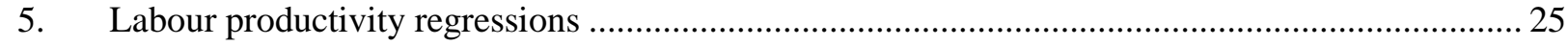

B1. Labour productivity difference between entry cohorts and old firms ......................................... 45

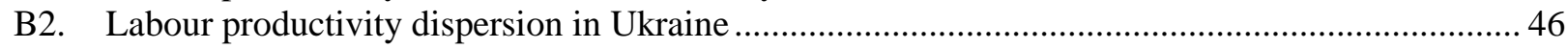




\section{Figures}

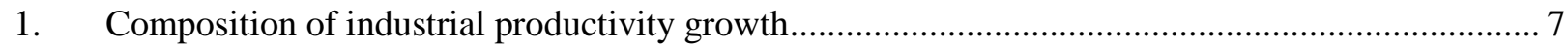

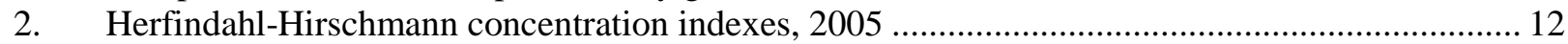

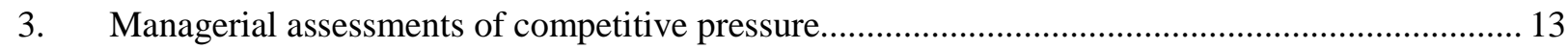

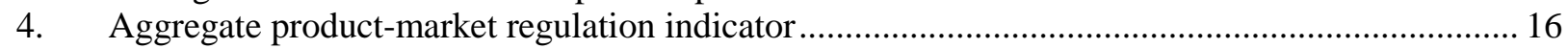

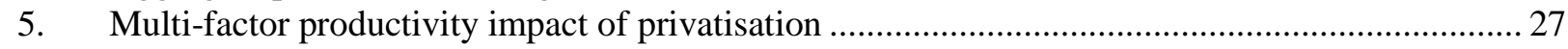

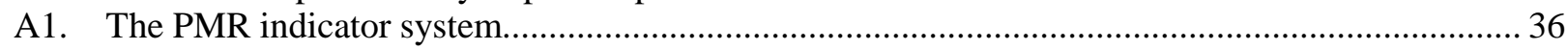

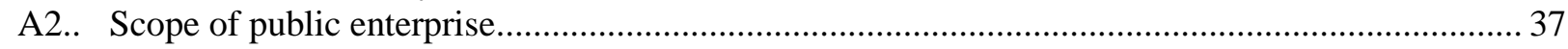

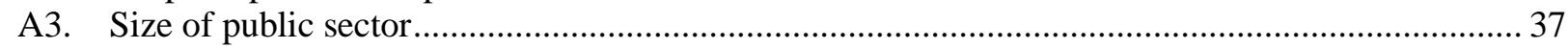

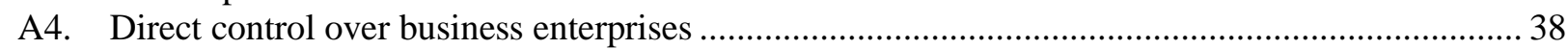

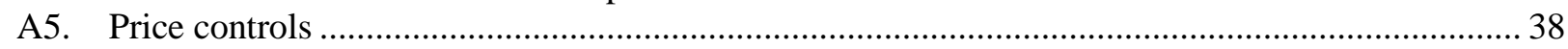

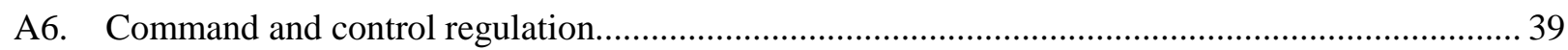

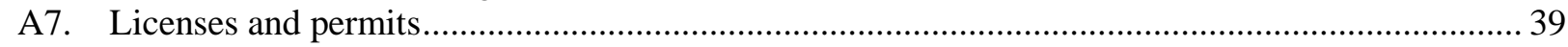

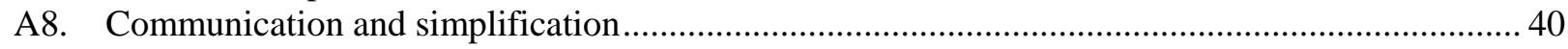

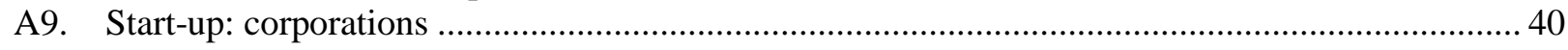

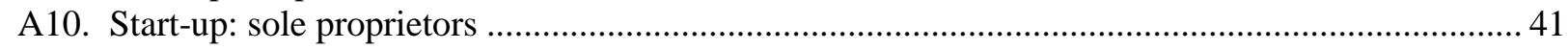

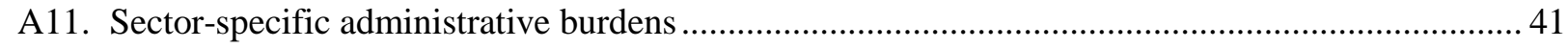

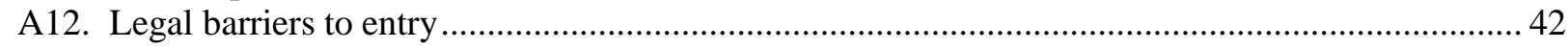

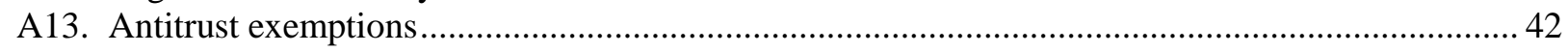

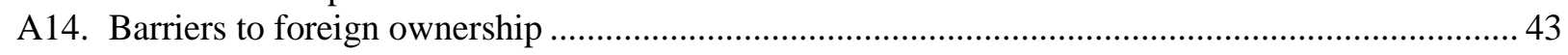

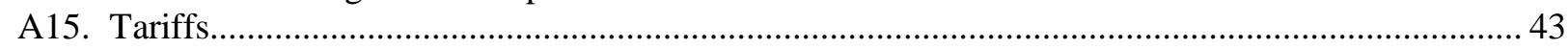

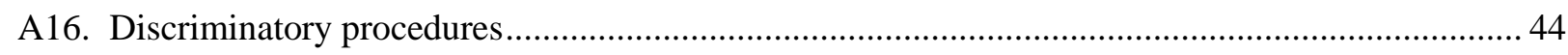

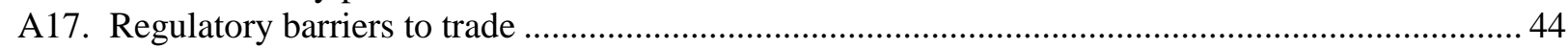


ECO/WKP(2007)34

\title{
TOO LITTLE DESTRUCTION, TOO LITTLE CREATION: A SCHUMPETERIAN DIAGNOSIS OF BARRIERS TO SUSTAINED GROWTH IN UKRAINE
}

\author{
Christian Gianella and William Tompson ${ }^{1}$
}

\section{Introduction}

One of the striking features of central planning was the extent to which it simply arrested the Schumpeterian processes of creative destruction that drive economic development in market economies. Competition was suppressed in favour of planning and there was virtually no exit - plants were rarely closed, the service lives of machinery were far too long, and little or no attention was paid to obsolescence. This, in turn, impeded entry, innovation and structural change, since it meant that established sectors, even in decline, continued to soak up investment and other resources that might have been more efficiently deployed elsewhere. Creating efficient mechanisms for entry, exit and reallocation - essential elements of dynamic, market-driven growth - was thus a first-order concern for all transition economies, including Ukraine. Yet while the post-independence period has indeed seen the gradual emergence of a Schumpeterian dynamic in Ukraine, it still rather muted. Competition is weak, entry and exit are limited, and a great deal of Ukrainian government policy continues to impede creative destruction by protecting incumbent firms and sectors from the rigours of the market. This has not prevented Ukraine from enjoying impressive growth over an extended period: real GDP growth averaged 7.4\% during 2001-06, as the economy bounced back from the severe transition recession of the 1990s. There is more at work here than simply a post-crisis recovery: the achievement of macroeconomic stabilisation together with the structural policies of the late 1990s did much to harden firms' budget constraints and unleash to some extent the forces of creative destruction. Yet sustaining strong growth over the long term is likely to prove extremely difficult unless the authorities take further steps to open up Ukrainian markets and allow needed structural change to unfold.

This paper considers both sides of the issue, looking at what has been achieved in terms of creating open and competitive markets in Ukraine and at the many barriers to entry, exit and reallocation that remain. It begins with an assessment of these processes in Ukraine today. The major conclusion that emerges from this analysis is that, while competition has been increasing in recent years and entry has become somewhat easier, exit mechanisms in Ukraine continue to function very poorly. The empirical

1. Economics Department, OECD, 2 rue André Pascal, 75775 Paris CEDEX 16, France; christian.gianella@oecd.org and william.tompson@oecd.org. Special thanks are due to Val Koromzay, Andrew Dean, Andreas Wörgötter, Patrick Lenain and Vincent Koen of the OECD for their comments on earlier drafts. This paper is based on work done in conjunction with the preparation of the 2007 OECD Economic Assessment of Ukraine, and the authors are grateful to Paul Conway of the OECD for his assistance with the PMR review, to Volodymyr Dubrovskiy, David Brown and John Earle for their involvement in the empirical work, and to Iryna Akimova and Pekka Sutela, who acted as external discussants when the Assessment was first presented at the OECD. The authors also appreciate the contribution of the many Ukrainian and western officials, experts and businessmen, too numerous to list here by name, who discussed these issues with the Assessment team. Last but not least, special thanks go to Corinne Chanteloup for research assistance, as well as to Sylvie Ricordeau and Josiane Gutierrez for secretarial assistance. Responsibility for any errors of fact or judgement that remain in the paper rests, of course, entirely with the authors. 
evidence suggests that Ukraine has too little exit overall and that the link between productivity and exit is very weak. The survival chances of entering firms appear to suffer from the existence of a large population of low-productivity incumbents that seem to be shielded from the rigours of the market. Continued public support for an oversized state enterprise sector emerges as one of the main impediments to more efficient exit.

Since the barriers to more robust competition are largely the product of excessive and often illadministered regulation, the second section of the paper presents a systematic assessment of productmarket regulation (PMR) in Ukraine, using indicators developed by the OECD Economics Department. The results show that the overall burden of regulation in Ukraine is extremely heavy by OECD standards. Barriers to business development appear to be more of a problem than barriers to entry, although the latter are by no means negligible, and regulatory process also emerges as a particularly serious issue for Ukraine.

Finally, the paper presents the main findings of two empirical studies concerned with the potential benefits of opening up markets, via both increased competition and further privatisation. The overriding conclusions that emerge from these two lines of analysis are as follows:

- Market concentration has a negative and highly significant impact on labour productivity growth: a one percentage point decline in the Herfindahl-Hirschmann Index is associated with an increase in labour productivity growth of the order of $0.2-0.3 \%$. Import competition has a positive impact on domestic firms' productivity.

- Further privatisation could play a major role in stimulating greater dynamism and flexibility, particularly in conjunction with competition-enhancing regulatory reform: in the case of privatisation to domestic owners, total factor productivity increases by between 10 and $25 \%$, depending on the specification used, during the seven years following privatisation.

As will be seen, the potential benefits arising from such reforms are likely to be particularly great in view of the complementarities that exist among them. Realising the full benefits of reform may thus require the creation of a broad, coherent and systematic framework for the conduct of regulatory policy, an area where policy-making in Ukraine has often been fragmented and poorly coordinated.

\section{Structural change in Ukraine since the financial crisis}

\section{Increasingly intensive job reallocation has been productivity enhancing...}

Productivity growth in industry was remarkably strong during 1999-2004 but slowed in 2005-06. Performance in manufacturing has been particularly impressive: manufacturing output rose by roughly $10 \%$ per year during 2001-06 and its share in total value added remained relatively stable at around $20 \%$, manufacturing employment fell by approximately $15 \%$ over the period. ${ }^{2}$ Productivity thus rose by a healthy $12.5 \%$ per year on average over 2001-06, despite a slowdown towards the end of the period. As expected, productivity growth has been significantly faster in industry than in services, especially nonmarket services. ${ }^{3}$ Productivity gains have been strong in most manufacturing sectors, ${ }^{4}$ which is hardly surprising in a phase of global recovery. These results in part reflect the more intensive use of production capacities: productivity gains have been somewhat stronger in industries that had more room to increase capacity utilisation.

2. The data refer to medium and large enterprises only.

3. See OECD (2007a:107).

4. Productivity growth has been particularly healthy in machine-building and wood products, where Ukraine has exhibited comparative advantages, while lagging in mining, metallurgy, and electricity production and distribution. 
Continued intensive labour-shedding also contributed significantly to the rise in productivity, at least until 2003 (Figure 1). This was undoubtedly a direct consequence of more active restructuring of firms, at a time when Ukraine was "catching up" on reforms in the transition process. While the speed of job reallocation between sectors and the pace of job creation were slower in Ukraine until the late 1990s, the rate of labour turnover and excess reallocation increased markedly at the end of the decade (see Table 1). The trend towards an increased fluidity of the labour market continued during 2000-06: the gross job turnover ratio, defined as the sum of hiring and firing over total employment, rose steadily, from around $45 \%$ in 2000 to $58 \%$ in $2005 .{ }^{5}$ Labour-shedding was particularly intense in the sectors which were most exposed to foreign competition: machine-building and, above all, light industry. In the latter, production has been increasing at a very modest pace, and productivity gains stem chiefly from falling employment. Since 2004, industrial employment has stabilised and productivity growth has slowed, which suggests that this phase of relatively "easy" restructuring is over.

Figure 1. Composition of industrial productivity growth

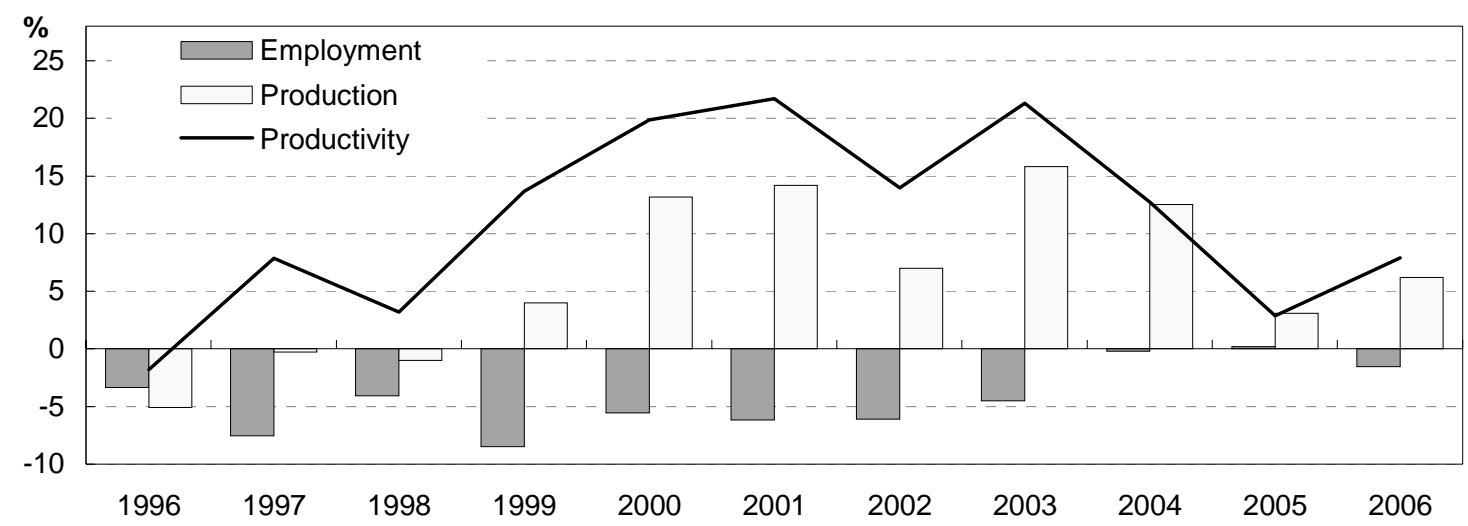

Source: Derived from State Statistics Committee of Ukraine.

Table 1. Year by year job flow rates

(Percent of total employment in the sampled firms)

\begin{tabular}{lccccc}
\hline & $\begin{array}{c}\text { Creation } \\
\text { Rate }\end{array}$ & $\begin{array}{c}\text { Destruction } \\
\text { Rate }\end{array}$ & $\begin{array}{c}\text { Reallocation } \\
\text { Rate }\end{array}$ & $\begin{array}{c}\text { Net } \\
\text { Change }\end{array}$ & $\begin{array}{c}\text { Excess } \\
\text { Reallocation }\end{array}$ \\
\cline { 2 - 6 } $1992-93$ & 1.1 & 8.3 & 9.4 & -7.2 & 2.1 \\
$1993-94$ & 1.2 & 11.6 & 12.7 & -10.4 & 2.3 \\
$1994-95$ & 1.3 & 11.1 & 12.4 & -9.8 & 2.6 \\
$1995-96$ & 1.6 & 11.2 & 12.7 & -9.6 & 3.1 \\
$1996-97$ & 1.6 & 11.2 & 12.8 & -9.7 & 3.2 \\
$1997-98$ & 1.7 & 10.0 & 11.7 & -8.3 & 3.4 \\
$1998-99$ & 2.4 & 10.1 & 12.5 & -7.7 & 4.9 \\
$1999-2000$ & 3.4 & 8.6 & 12.0 & -5.2 & 6.8 \\
\hline
\end{tabular}

Note: These flows are computed according to the methodology proposed by Davis and Haltiwanger (1992) but only on continuing firms, omitting flows associated with firm entry and exit.

Source: Brown and Earle (2004). 
These findings on the role of labour-shedding are reinforced by a comparative analysis of the relationship between firms' deviations from average labour productivity in their sectors and their employment share. This measures the degree to which employment reallocation is productivity-enhancing. The results in Table 2 show that the relationship across the entire period is far stronger in Ukraine and Russia than Romania and particularly Hungary. In part, of course, the fact that labour reallocation has been more productivity-enhancing in Russia and Ukraine probably reflects the inefficiencies and structural distortions that existed in those countries at the start of the transition: misallocation of labour was less of a problem in Hungary than in most transition countries, and it was generally worse in former Soviet republics than in Central Europe. ${ }^{6}$

Table 2. Correlation between labour productivity deviation and employment share change

\begin{tabular}{lcccc}
\hline & $\mathbf{1 9 9 2 - 1 9 9 5}$ & $\mathbf{1 9 9 5 - 1 9 9 8}$ & $\mathbf{1 9 9 8 - 2 0 0 1}$ & $\mathbf{2 0 0 0 - 2 0 0 3}$ \\
\cline { 2 - 4 } Hungary & 0.013 & 0.040 & 0.009 & 0.020 \\
Romania & 0.055 & 0.048 & 0.040 & 0.048 \\
Russia & 0.113 & 0.136 & 0.113 & 0.105 \\
Ukraine & 0.092 & 0.134 & 0.083 & 0.095 \\
\hline
\end{tabular}

Note: These are correlations between, and the firms' deviations from, sector labour productivity in the initial year and employment share changes between that and the next year. Entrant labour productivity is measured in the second year. The averages across the first two two-year periods within each four-year period are reported (i.e., for 1992-95, it is the average of 1992-93 and 1993-94).

Source: Brown and Earle (2007a).

\section{...but entry and particularly exit mechanisms still works poorly...}

A large and growing body of cross-national empirical work suggests that creative destruction remains critical to economic progress: higher firm turnover (i.e. higher entry and exit) is growth-enhancing. ${ }^{7}$ Moreover, as noted above, eliminating, or at least minimising, barriers to entry, exit and reallocation of resources is particularly critical in transition economies. Because the restructuring of large state-owned enterprises (SOEs) is fraught with difficulty and often subject to considerable delay, reducing barriers to entry is particularly important: the entry of new enterprises and the growth of new activities has been a crucial engine of transformation in the more successful transition economies. Ukraine still has much to do on this score. Its small business sector is relatively under-developed and, on some indicators, it appears to be losing ground relative to the rest of the economy. While the official data are difficult to interpret, it seems clear that small business is developing far less robustly in Ukraine than in the transition countries of Central Europe or even in Russia. ${ }^{8}$ The economy - particularly the industrial sector - is still dominated by the heavy industries that Ukraine inherited from the Soviet Union. Some of these sectors have been restructuring successfully, but their continuing dominance is one reason why so much policy since 1992 has been oriented towards averting rather than facilitating structural change. Efforts to protect established enterprises and sectors - in essence, impediments to exit - have helped retard the development of new

6. Ernst et al. (1995) compare the USSR, China, Poland, Hungary and the Czech Republic with respect to three indicators of readiness for the market transition - structural misdevelopment, institutional preparedness for a market economy, and macroeconomic disequilibrium - concluded that the Soviet economy was by far the least prepared on all three dimensions.

7. See the overview of the Schumpeterian approach in Aghion and Howitt (2006).

8. Data on small businesses are highly problematic and the actual situation is probably better than the official statistics suggest. Nevertheless, the growth and productivity performance of small businesses since 2000 looks decidedly unimpressive compared to what has been observed in neighbouring countries. See OECD (2007), Annex 2.A2 for details. On Russia, see OECD (2004a). 
activities. Such pressures are not difficult to understand, given the fear of the costs of transition in the short term, but from a long-run perspective, policies that inhibit entry and exit can only be regarded as perverse. While there has recently been some progress in making entry easier, impediments to entry, exit and restructuring remain substantial.

Empirical analysis confirms the impression that Ukraine has particular problems with exit. Censustype, firm-level data for Ukraine show overall firm turnover rates in manufacturing (entry plus exit) to be rather low by OECD standards - about $10 \%$ in 2002-05, as against rates of $15-20 \%$ typically found in mature market economies. ${ }^{9}$ As is evident from the data in Table 3 (row a), the level of exit is particularly low. Entry is now less of an issue than it was: a comparison of firm-level data for Hungary, Romania, Russia and Ukraine shows extremely low levels of entry in Ukraine in the early 1990s, but entry rates rise sharply after 1995, reaching levels roughly comparable to Russia's. When weighted by share of output, entry in Ukraine compares reasonably well to Hungary and Romania, as well as Russia (Table 3, row b). Moreover, entering firms in Ukraine are significantly more productive than incumbents - around $40 \%$ more productive on average, for the entire period from 1992 through 2005 (Table 3, row c). ${ }^{10}$ This means that entry has been particularly good for aggregate productivity; it may also reflect entrants' awareness of the difficult conditions in which they will operate - they will need to be exceptionally efficient to have a reasonable chance to survive and grow. ${ }^{11}$ This may be one reason why two-year survival rates in Ukrainian manufacturing - above $80 \%$ in the most recent period - are close to the highest rates found in developed OECD economies. ${ }^{12}$

The exit data suggest that one of the difficulties entrants face is that competitive conditions are by no means equal and that the selection of firms for exit is only weakly linked to performance. Exit rates in Ukraine are lower than in any of the other countries under study across the entire 1992-2003 period, and a number of indicators suggest that exit mechanisms in Ukraine are doing a poor job of ensuring that it is the less productive firms that exit the market. As one would expect, exiting firms are much less productive than survivors on average (Table 3, row d). However, the negative correlation between exit and productivity is weak in Ukraine, and there is no evidence to suggest that it is increasing over time (Table 3, row e). In Russia and Romania, the correlation tends to be about three times as strong as in Ukraine, and it is somewhat stronger in Hungary as well. More disturbing still is the fact that exiting new private firms are significantly more productive than surviving old firms (defined as those existing prior to the transition or ever having been state-owned), though they are somewhat less productive than surviving entrants (Table A2.1). This sort of "unnatural selection" for survival or exit is particularly evident in the production of machinery and equipment, electrical and optical apparatus, pulp and paper, and publishing and printing.

These results suggest that there is too much exit of new private firms in Ukraine, and too little exit of older firms. The fate of new entrants seems to be less clearly linked to productivity than it ought to be. This may be one reason why Ukraine also exhibits exceptionally high - and rising - labour productivity

9. Scarpetta et al. (2002) provide estimates for leading OECD economies for the early 1990s.

10. This is a striking result, albeit one also observed in Russia. The average productivity of entrants is generally lower than that of incumbents. Entrants are usually more productive than weak firms in a given sector but they may still be, initially at least, less productive than the average firm.

11. In Russia, too, the higher productivity of entrants may reflect the higher hurdles to be surmounted.

12. See Scarpetta et al. (2002) for estimates of survival rates in the major OECD countries. 
Table 3. Entry, exit and labour productivity differences, 1992-2005

\begin{tabular}{|c|c|c|c|c|c|c|c|c|c|}
\hline & & \multicolumn{2}{|c|}{$1992-1995$} & \multicolumn{2}{|c|}{$1995-1998$} & \multicolumn{2}{|c|}{$1998-2001$} & \multicolumn{2}{|c|}{$2002-2005$} \\
\hline & & Entry & Exit & Entry & Exit & Entry & Exit & Entry & Exit \\
\hline (a) & Entry/exit: share of firms ${ }^{1}$ & 1.67 & 2.34 & 6.34 & 2.77 & 6.34 & 3.66 & 6.65 & 3.70 \\
\hline (b) & Entry/exit: share of output ${ }^{1}$ & 0.90 & 1.10 & 2.97 & 2.10 & 3.36 & 1.22 & 1.98 & 2.12 \\
\hline (c) & Entry-incumbent labour productivity difference ${ }^{2}$ & \multicolumn{2}{|c|}{18.9} & \multicolumn{2}{|c|}{54.9} & \multicolumn{2}{|c|}{76.9} & \multicolumn{2}{|c|}{10.6} \\
\hline (d) & Exit-survivor labour productivity difference ${ }^{3}$ & \multicolumn{2}{|c|}{-43.1} & \multicolumn{2}{|c|}{-39.8} & \multicolumn{2}{|c|}{-28} & \multicolumn{2}{|c|}{-30.8} \\
\hline (e) & Labour productivity deviation-exit correlation ${ }^{4}$ & \multicolumn{2}{|c|}{-0.09} & \multicolumn{2}{|c|}{-0.10} & \multicolumn{2}{|c|}{-0.03} & \multicolumn{2}{|c|}{-0.07} \\
\hline
\end{tabular}

1. The entry rates are averages for the second and third years in each four-year period, and the exit rates are the averages of the second, third and fourth years in each four-year period.

2. Percentage differences between the unweighted average labour productivity of first-year entrants and that of incumbents. The reported numbers are averages for the second and third years in each four-year period.

3. Percentage differences between the unweighted average labour productivity of firms exiting in the next year and that of survivors. The reported numbers are averages for the first, second and third years in each four-year period.

4. Correlations between firms' deviations from sector labour productivity and exit in the following year. Entrant labour productivity is measured in the second year.

Source: Brown and Earle (2007a).

dispersion within sectors throughout the transition period (Table A2.2). ${ }^{13}$ By 2005, Ukraine had an unusually large share of firms with labour productivity more than $50 \%$ below the sectoral mean $(37.2 \%)$ and yet the smallest share of output produced by such firms $(2.6 \%)$. This points to the existence of a very large population of small, unproductive firms that are neither being selected for exit nor compelled by competitive pressures to raise their productivity in order to survive.

These results suggest that there is too much exit of new private firms in Ukraine, and too little exit of older firms. The fate of new entrants seems to be less clearly linked to productivity than it ought to be. This may be one reason why Ukraine also exhibits exceptionally high - and rising - labour productivity dispersion within sectors throughout the transition period (Table A2.2). ${ }^{14}$ By 2005, Ukraine had an unusually large share of firms with labour productivity more than $50 \%$ below the sectoral mean $(37.2 \%)$ and yet the smallest share of output produced by such firms $(2.6 \%)$. This points to the existence of a very large population of small, unproductive firms that are neither being selected for exit nor compelled by competitive pressures to raise their productivity in order to survive.

\section{...and competition remains weak}

Given such low levels of entry and exit, it is no surprise that product markets in Ukraine are not, as a rule, characterised by robust, dynamic competition. On the contrary, markets tend to be highly concentrated and heavily regulated. The country's competition authority, the Anti-Monopoly Committee of Ukraine (AMCU), estimates that firms operating in sectors characterised by the structural pre-conditions for competition - that is, by the absence of monopoly or the concentration of substantial market power in

13. Estimates for 18 NACE two-digit manufacturing sectors show that the productivity difference between firms in the 10th and 90th percentiles in 2005 had reached an average of 4.03, and in only one sector was this figure below 3.5. In neighbouring Hungary, by contrast, the corresponding figures for all sectors but one were below 3 .

14. Estimates for 18 NACE two-digit manufacturing sectors show that the productivity difference between firms in the 10th and 90th percentiles in 2005 had reached an average of 4.03, and in only one sector was this figure below 3.5. In neighbouring Hungary, by contrast, the corresponding figures for all sectors but one were below 3 . 
the hands of one or a few firms - generated only around 55\% of total sales in 2004, against roughly $45 \%$ of sales arising in situations of monopoly, market dominance or oligopolistic competition. ${ }^{15}$ In many cases, the less competitive markets are in heavy industrial and infrastructure sectors, where high levels of capital intensity constitute barriers to entry. ${ }^{16}$ The Committee notes that this assessment is based solely on market structure; it omits regulatory and other interventions in product markets that reduce or eliminate competition where it might otherwise be expected to develop. ${ }^{17}$ As will be seen below, these additional impediments to competition are considerable. The AMCU's estimates correspond fairly well to the results of managerial surveys concerning the level and intensity of competition in particular markets. ${ }^{18}$

They also find confirmation in the Herfindahl-Hirschmann indexes (HHIs) shown in Figure 2. Calculated on the basis of a 5-digit classification, the indexes show very high degrees of market concentration overall. Indeed, they are higher than the comparable indicators for Russia in every major sector. Concentration levels have tended to rise in key export sectors in recent years, including metallurgy, chemicals, machine-building and food, while they have declined modestly in the construction materials and light industries. Figure 2 also shows that competition is much weaker at regional level, which suggests a high degree of segmentation between regional markets. This segmentation, which owes much to the actions of sub-national governments, is particularly evident in the gap between national- and regional-level HHIs for the food industry, a sector in which regional and municipal authorities are particularly prone to intervene.

In certain sectors, the high levels of market concentration reflect the relatively large share of output that is generated in highly monopolised and largely unrestructured network industries. In 2006, more than 2300 companies were classified as "natural monopolies", ${ }^{19}$ most notably in sectors such as gas, electricity, heat and other municipal utilities, as well as rail transport and telecommunications. Around ten of these were national-level players, with the rest dominating specific regional or local markets. To these one might add a few important but rather less natural monopolies, such as RosUkrEnergo, the controversial Swissregistered company that in 2006 became a monopoly supplier of Russian and Central Asian natural gas to

15. See AMCU (2006) for details. The committee estimates that $9 \%$ of sales were in monopoly-dominated sectors and a further 35-36\% in sectors characterised by market dominance or oligopolistic competition.

16. Examples include mining (apart from coal and peat), coke production, mobile and terrestrial telephony, brewing, tobacco and motor fuels, as well as some sub-sectors of chemicals and machine-building.

17. AMCU (2006), esp. at Table 3 and Figure 3.

18. According to NTK (2006), 52\% of managers described competition on the markets in which they were operating as "substantial"; $34 \%$ called it "moderate" and $14 \%$ weak or non-existent.

19. In Ukraine, the term "natural monopolies" generally does not bear the meaning it would in any western economics text (minimum efficient scale of production equal to or greater than the size of the market). Rather, it refers specifically to a number of infrastructure monopolies - above all, transmission and distribution of electricity, pipeline transport, rail transport, air traffic control, water supply and supply of some specialised port and airport services. See "About natural monopolies" (2005). 
Figure 2.. Herfindahl-Hirschmann concentration indexes, 2005
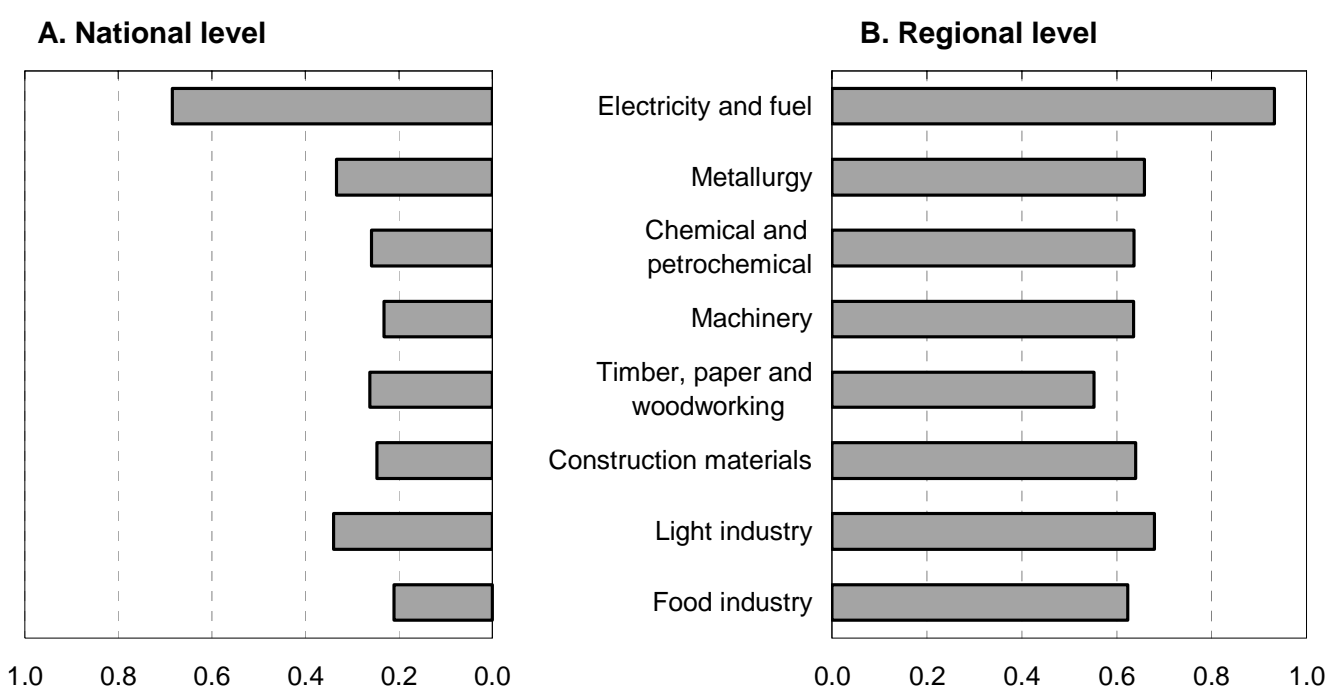

Source: OECD calculations using the register of Ukrainian enterprises, 2000-05.

Ukraine, and its domestic arm Ukrgaz-Energo. ${ }^{20}$ Despite the large role played by such companies in the economy, monopolies regulation in Ukraine is almost uniformly weak and the reform of major infrastructure sectors has made little progress. Tariff-setting for regulated monopolies tends to be opaque, fragmented and highly politicised. As a result, monopoly suppliers in some spheres are required to undercharge, providing implicit subsidies to some or all of their consumers, while in other sectors, there is evidence of spectacular profits being earned by regulated industries. In either case, the result is inefficient spending and the distortion of competition, not only in network industries but in other sectors as well: mispriced energy, for example, biases competitive conditions in favour of less energy-efficient firms and sectors.

While the concentration measured by HHIs has not decreased significantly over the last five years, managerial surveys suggest that pressure from domestic and foreign competitors increased steadily in the early 2000s, although foreign competition appears to remain a negligible factor for most domestic firms (Figure 3). ${ }^{21}$ This result is not as paradoxical as it might appear. The strength of competition depends not only on the degree of market concentration or the development and enforcement of competition law, but also on trade policy, the creation of an effective bankruptcy mechanism, privatisation and sectoral regulatory policies - in other words, on the whole complex of policies and institutions that allow the threat of competition to emerge. Thus, although both the legal instruments and the institutions concerned with competition policy have been improving, the increasing intensity of competition probably owes more to privatisation, liberalisation and stabilisation than to competition policy per se..$^{22}$

20. Ukrgazenergo is a 50/50 joint venture of RosUkrEnergo and Naftogaz Ukrainy; see IEA (2006), Chapter 6, for details.

21. See, in particular, NTK (2006) and IERPC (2006). Note, however, that IERPC (2006) sees some evidence that the degree of competitive pressure either stabilised or even fell slightly after 2004.

22. See the overview in Stotyka (2004). 
Figure 3. Managerial assessments of competitive pressure

Share of enterprises reporting competitive pressure as a constraint on growth

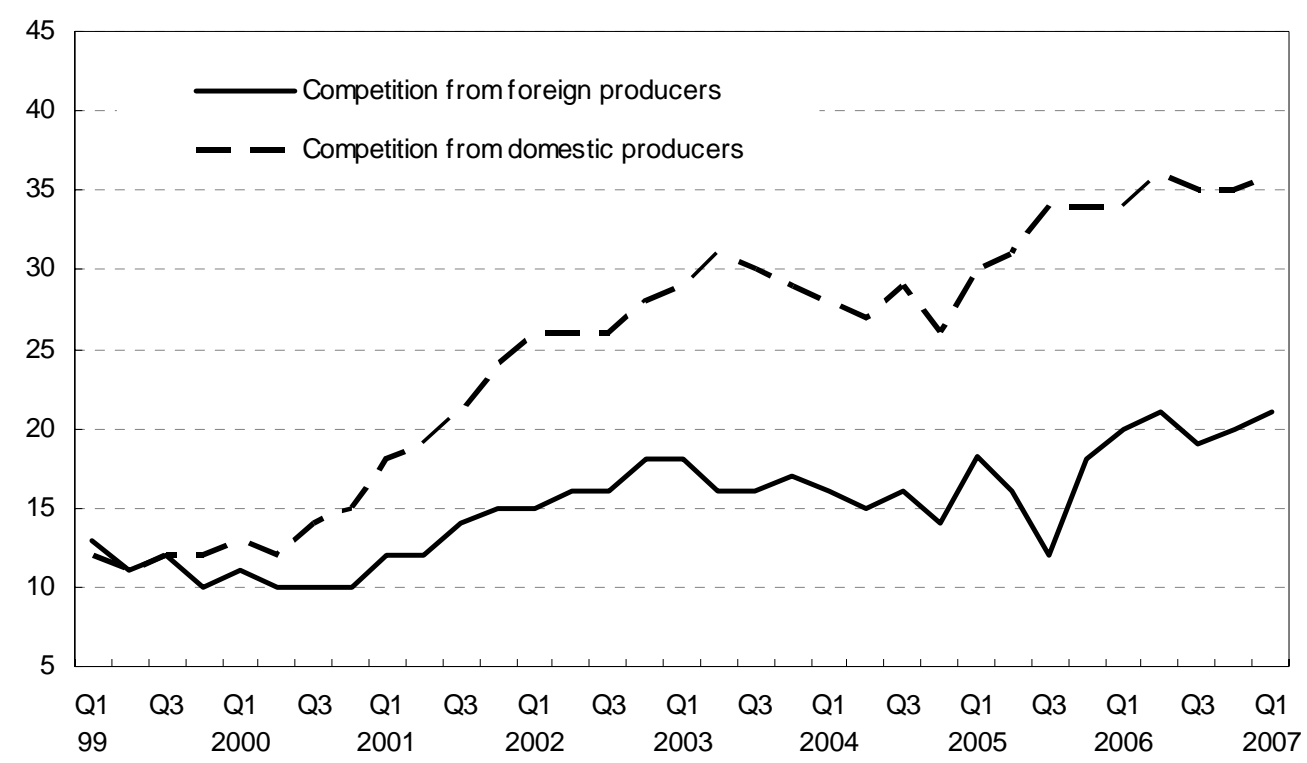

Source: Scientific and Technical Complex for Statistical Research.

\section{Competition policy has improved but much remains to be done}

High levels of market concentration and weak competition are partly a product of Ukraine's inherited economic structure, but they are also, in large measure, the product of misguided policies. Throughout the transition period, successive Ukrainian governments have adhered to a wide range of practices aimed at supporting existing economic sectors and protecting incumbent firms. To be sure, competition law is now much improved and, on paper at least, it is broadly in line with international norms, ${ }^{23}$ but anti-competitive policies and practices are still widespread. ${ }^{24}$ The barriers to exit outlined above serve to suppress competition and thus to delay rather than to facilitate needed structural change. This cannot but impede any attempt to enhance Ukraine's competitiveness over the long term, since the most potentially competitive firms and sectors are handicapped by the cost of supporting less efficient rivals. Broadly speaking, weak competition in product markets reflects not only economic barriers, but the interaction between market structures, regulatory practices and weak institutions.

- Market structures largely define the terrain on which competition law is applied. Given the presence in Ukraine of so many sectors with relatively high degrees of concentration, it is not surprising that roughly half the AMCU's caseload concerns alleged or actual abuse of dominant position. Most of these concerned monopoly pricing or attempts to restrict supply to particular customers or markets. As the economy has matured and Ukrainian industrial organisation has become more complex, the importance of collusion has grown, but dominance cases are still the most common.

23. See OECD (2007a:119).

24. See IERPC (2003) for an excellent overview. 
- The significance of regulatory practice is highlighted by the fact that fully one-quarter of the AMCU's caseload in 2000-05 consisted of cases against public authorities engaged in actions that reduced, distorted or eliminated competition in particular markets. The great majority of these cases were in markets where the structural preconditions for competition did exist. A large proportion concerned the deliberate administration of various regulatory regimes - ranging from sanitation and fire-safety to standardisation and certification - so as to limit competition or prevent entry.

- These problems are compounded by the weakness of institutions in Ukraine. The weakness of the rule of law in general, and of the court system in particular, means that entrepreneurs are hesitant to rely on law to seek redress in the event of unfair competition. More generally, agents recognise that the ability of rivals to tap "administrative resources" - i.e. to draw on the implicit or explicit favour of state bodies - can enable them to violate competition rules with impunity. ${ }^{25}$ This awareness creates incentives to accumulate administrative resources of one's own: firms that do not develop the necessary relationships with key public officials will suffer for it, so even managers who might prefer (and profit from) fair, transparent, rules-based competition must play this game. ${ }^{26}$

The prevalence of anti-competitive regulatory practice (which is illegal under the Law on Regulatory Policy) underscores the link between competition issues and the kind of regulatory reform discussed in conjunction with the PMR assessment presented below. The AMCU reckons that, if formal and informal barriers between regional and local markets are taken into account, then the proportion of sales generated in markets where the conditions for robust competition prevail stands as low as 30\%: in many regions, competition is restricted not only in such spheres as housing and utilities, which are still dominated by SOEs and municipal enterprises, but also in food and food-processing, retail trade, transport and construction. This view is confirmed to some extent by the very high regional HHIs presented above. Yet the AMCU data tell only part of the story: much of the anti-competitive behaviour of state and municipal institutions is perfectly legal and is therefore not reflected in AMCU enforcement statistics. Implicit and explicit subsidies to selected companies and sectors (particularly SOEs) distort competition, as do many other initiatives taken in the name of local or national "industrial policies" that effectively privilege "priority" sectors at the expense of others.

A consistent, broad-based policy of de-regulation could also do much to address these problems, since excessive and often inconsistent regulation tends to create opportunities for arbitrary bureaucratic action, favouritism and rent-seeking. However, in many spheres, Ukraine needs better regulation rather than simply less regulation. This will require correcting the many gaps and contradictions that exist in legislative and regulatory frameworks, as well as evolving a more coherent approach to regulatory policy overall.

\section{Reducing barriers to entry, exit and reallocation: the role of product-market reform}

Regulatory reform can make a significant contribution to resolving the problems identified above, by reducing barriers to entry and removing obstacles to firms' growth once they have entered the market. Recent empirical work on product-market regulation (PMR) highlights the extent to which restrictive regulations impede entry and slow the diffusion of new technologies and practices across firms and

25. Official favouritism is a widely recognised problem: an IFC managerial survey in 2003 found that $61 \%$ of respondents regarded unequal conditions of competition as a serious or very serious problem for their businesses.

26. See the survey data in IERPC (2006:5) on the importance of cultivating informal relationships with municipal, provincial and central government officials. 
sectors. ${ }^{27}$ Competition-enhancing PMR reform can help raise productivity growth through a number of channels, including the direct impact of competition on both market efficiency and technical efficiency, ${ }^{28}$ as well as its indirect impact via the role of competition in spurring innovation. ${ }^{29}$ Finally, Alesina et al. (2003) find that reforms which liberalise entry are likely to spur fixed investment in some sectors. Regulatory reform thus has a role to play in addressing a host of economic challenges identified in this report: reducing impediments to entry and business development, stimulating competition, raising the investment rate and attracting FDI.

\section{The regulatory framework in Ukraine: a comparison with OECD countries}

With these considerations in mind, the OECD Secretariat in early 2007 undertook an assessment of Ukraine against the product market regulation (PMR) indicators developed by the OECD Economics Department in recent years. ${ }^{30}$ The indicators are based on detailed questionnaires concerning regulatory policy, which are submitted by the Secretariat to participating governments. This makes it possible to benchmark Ukraine's regulatory policies against those of OECD members, and to draw more easily on the experience of OECD members in identifying those areas in which regulatory reform might be most profitable. The questionnaires are divided into three broad groups: domestic barriers to entrepreneurship, state control and barriers to trade and investment. This permits an assessment of both inward- and outwardoriented policies. (Annex A describes the PMR review process in more detail and presents the full results for Ukraine.)

Before examining specific indicators, it is worth highlighting four broad conclusions that emerge from the PMR review of Ukraine:

- The level of overall product-market regulation is higher than that of any OECD country in 2003 (Figure 4) ${ }^{31}$ It should be noted, moreover, that many of the poorer performers in the OECD's 2003 PMR assessment have since undertaken regulatory reforms: Poland, for example, has adopted legislation to reduce substantially the administrative burdens on start-ups and has taken steps to reduce uncertainty about the application of tax regulations.

27. See Conway et al. (2006), especially on the diffusion of information and communications technology and the location decisions of multi-national enterprises. See also Lewis (2004) for the results of a large body of micro-level studies of industries in 13 countries conducted by the McKinsey Global Institute.

28. Nicoletti and Scarpetta (2003); Conway et al. (2005).

29. Aghion et al. $(2001,2005)$.

30. The indicators for Ukraine were calculated based on the regulatory policies in place at end-March 2007. In some cases, policy settings have changed since then.

31. Ukraine's ranking on the aggregate PMR indicator is in part a reflection of its exceptionally low score, relative to all OECD members, on the indicator for regulatory barriers (Figure A1.17). However, it would be a mistake to assume that the outcome shown in Figure 2.1 is merely a statistical artefact: if Ukraine's regulatory barriers score were reduced to the level of Germany or Denmark, its overall PMR ranking would leave it just ahead of Poland (2003) but still behind Turkey (2003). Ukraine scores poorly even on aggregate indicators that zero-weight the regulatory barriers indicator. 
Figure 4. Aggregate product-market regulation indicator

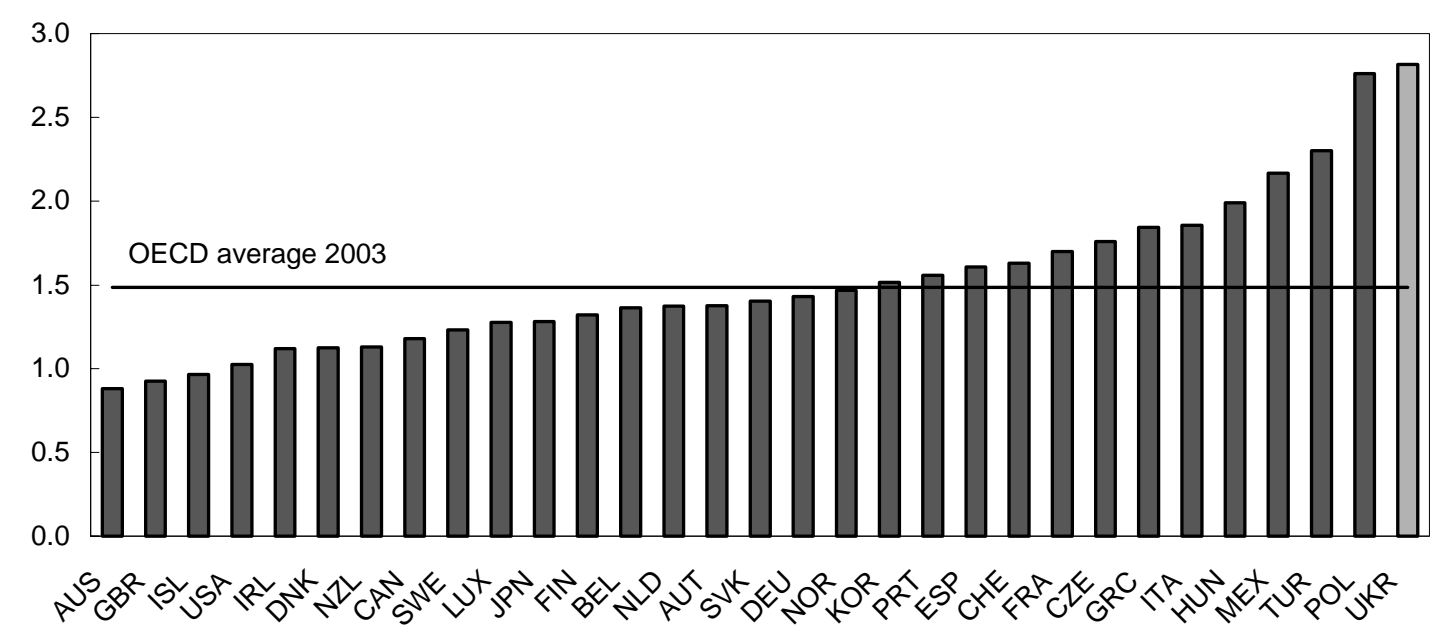

- The burden of product-market regulation is well above the OECD average with respect to all three major components of the aggregate indicator: state control, barriers to entrepreneurship and barriers to trade and investment (Table 4). However, it should also be noted that Ukraine does relatively well on a number of the sixteen individual indicators, particularly in areas where reforms have recently been enacted. The level of sector-specific regulation is also comparatively low, as Ukraine has adopted a fairly liberal stance with respect to a number of industries that are often heavily regulated elsewhere.

Table 4. Summary indicators of product-market regulation

\begin{tabular}{|c|c|c|c|c|c|}
\hline & \multicolumn{3}{|c|}{ OECD } & \multirow{2}{*}{ Ukraine } & \multirow{2}{*}{ Brazil } \\
\hline & Average & Low & High & & \\
\hline Product-market regulation & 1.5 & 0.9 & 2.8 & 2.8 & 1.9 \\
\hline State control & 2.1 & 0.6 & 3.6 & 2.7 & 2.5 \\
\hline Barriers to entrepreneurship & 1.5 & 0.8 & 2.5 & 2.4 & 1.3 \\
\hline Barriers to trade and investment & 1.0 & 0.3 & 2.4 & 3.3 & 1.9 \\
\hline
\end{tabular}

- Overall, barriers to business growth appear to be more constraining than barriers to entry.

- Regulatory process is in some respects as much of a problem as the substance of regulation. Ukraine scores rather poorly on indicators concerned with such issues as the formulation of regulatory policy and effective communication with the business community. ${ }^{32}$

The problem of poor regulatory process reflects in part a failure to define with clarity the various roles that the state is expected to play in the economic life of the country or to differentiate between them in ways that avoid undesirable conflicts of interest, particularly where commercial activities and the state's ownership function overlap with its regulatory and policy-making functions. Developing a clearer, more coherent understanding of the state's role in a market economy thus represents one of the most basic challenges of regulatory reform. 
Analysis of the specific PMR indicators provides a much richer picture, albeit one consonant with these general conclusions. However, when interpreting the detailed results of the PMR review, it should be borne in mind that the questionnaires represent an assessment of formal regulatory policy settings: they do not provide any information about the way in which these policies are implemented. In the case of Ukraine, this is a particularly important point in view of its institutional weaknesses. Widespread official corruption, the weakness of the rule of law, the inefficiency of public bureaucracies and the often confused and incomplete character of legal and regulatory frameworks mean that the actual regulatory policies may deviate from, or even contradict, formal policy settings. In many instances, formal regulatory policies appear to have improved substantially, but the implementation of those policies remains incomplete and inconsistent. Nevertheless, it would be a mistake to conclude that legislative or regulatory reform is ineffective or unimportant: it is neither. As will be seen, a good deal of evidence suggests that improvements in formal policy settings do result in real improvements in the business climate even when implementation is patchy; however, the effects are less pronounced, less predictable and less widespread than they would be in a better institutional setting.

\section{Conditions for start-ups are easier, but barriers to entry for foreigners remain very high}

One area where Ukraine ranks relatively well concerns the procedures for starting a new business. Ukraine is well below the OECD average on the start-up indicator for new companies and only slightly above it on the indicator for sole proprietors (Figures A9 and A10). This would appear to reflect recent efforts to improve conditions for entry. Moreover, other evidence suggests that, despite incomplete implementation, new legislation aimed at creating a "one-stop shop" registration process for new businesses really has had a marked positive effect. ${ }^{33}$ In a significant minority of cases (around $25 \%$ for legal persons and $30 \%$ for private entrepreneurs) registration still takes longer than the law envisages, though officials attribute many of the delays to failure on the part of applicants to prepare the necessary documentation ahead of time. ${ }^{34}$ Broader questions of entry are addressed below, but it is important to note in this context that, despite the recent changes, start-up procedures remain costlier and more timeconsuming in Ukraine than in most of the region. The simplification of registration procedures has reduced the gap significantly but it has not closed it. The remaining problems concern the many post-registration procedures a new business must go through before starting to operate. ${ }^{35}$

The situation facing would-be foreign entrants is somewhat more complex. On the whole, Ukraine's economy is in many respects quite open, and this is reflected in the PMR indicator for barriers to foreign ownership (Figure A14). This shows Ukraine close to the OECD average in terms of restrictions on foreign acquisitions in "sensitive" sectors - though the indicator fails to pick up quite serious restrictions on foreign investors' acquisition of land. ${ }^{36}$ Regulatory barriers, however, are another matter (Figure A17). The principle of national treatment in respect of regulatory policy is not enshrined in law, and foreign companies do not, as a rule, have the right to seek redress through the competition authority, trade policy bodies or regulatory agencies. Ukrainian legislation does not require regulators to use internationally harmonised standards and certification procedures whenever possible and appropriate. While the authorities have in recent years laid great stress on the need to bring primary and secondary legislation into

33. A major survey of entrepreneurs showed that they were broadly satisfied with the new arrangements; see "Derzhavna" (2006). Between 2005 and 2006, Ukraine rose 21 places on the "start-up" indicator of the World Bank's "Doing Business" data base, which is based on assessments of the actual time and cost involved, rather than the formal rules.

34. See the survey data in ICS (2006) and "Derzhavna" (2006).

35. Including registration with the tax inspectorate, the various social insurance funds and other public bodies.

36. See EBA (2006:31-8). 
line with international (and, in particular, EU) norms, local standardisation and certification requirements, many of them left over from the Soviet era, continue to be applied. This complicates both foreign trade and investment, since it greatly adds to the cost of introducing (via imports or local production) products that are new to the Ukrainian market, even if these have been certified elsewhere. This problem is compounded by the overlapping jurisdictions of various regulatory bodies, which mean that the very same goods and services may be subject to inspection and certification on precisely the same grounds by a number of different agencies. Progress in reducing the redundancy in certification and standardisation has been limited, owing largely to resistance from the regulatory bodies involved. ${ }^{37}$ Finally, it should be noted that Ukraine has not engaged in mutual recognition agreements with any other countries.

\section{Overregulation impedes business growth and development}

While market entry in Ukraine has recently become somewhat easier, the regulatory impediments to growing businesses of whatever size remain extremely onerous. As noted above, the sheer complexity of regulation - much of it unnecessary - is difficult to exaggerate. The authorities are well aware of this and, in an effort to address the problem, they undertook a "quick de-regulation initiative" in 2005. This involved a review of 9340 national regulations, of which 5184 were found to violate the law on regulatory policy. Some 4940 were amended or repealed. ${ }^{38}$ In addition, no fewer than 66 presidential decrees were found to be in violation of the law. Unfortunately, phase 2 of the initiative, which was to be focused on sectoral legislation, never took place, despite having been authorised by the president, and the process of issuing new regulations carried on unabated. In any case, it is impossible to judge the impact of such an exercise in terms of the number of rules abolished: critics argue that the vast majority of the regulations that were scrapped were no longer being applied anyway, and the review was not accompanied by any systematic assessment of the quality of the regulations that remained. ${ }^{39}$

Particularly problematic in this context is the regulatory burden associated with licensing and permits: on this indicator, Ukraine ranks alongside the most heavily regulated OECD members (Figure A7). One of the biggest complaints of entrepreneurs in Ukraine concerns the pervasive system of permits, which businesses have to obtain and renew regularly in order to engage in almost any form of commercial activity. ${ }^{40}$ This is, of course, a barrier to market entry - ordinarily, an entrepreneur starting a new business must secure a large number of different permits before he can start operating - but it is not limited to startups, since the vast majority of permits must be renewed at regular intervals. It therefore marks an impediment to the development of any business. The situation with respect to permits (but not licences) has recently improved markedly. A law on the permit system was adopted in late 2005, in an effort to engineer a radical reduction in the number of permits issued by central, regional and local authorities. In order to ensure that the law's effect was not limited to a one-off reduction in the number of permits, it introduced new restrictions on the ability of state agencies and municipalities to create new permits. Yet even in the wake of this undoubtedly important reform, Ukraine still compares very poorly to the great majority of OECD members when it comes to licensing and permits. In fact, the situation is probably somewhat worse than it appears, since the implementation of the new law on permits is still far from complete: a number of other statutes have yet to be brought into line with the law on the permit system, and many state and

37. Perhaps the most striking example here has been resistance to implementation of the 2005 food safety law, which sought to put an end to triple control of all food imports - by the veterinary and sanitation inspectorates (separately), as well as by the standards body, the State Committee for Technical Regulation and Consumer Policy.

38. The corresponding figures for local regulations reviewed were 5 386, 1750 and 1358 , respectively. See "Shchodo" (2006).

39. Balcerowicz and Ustenko (2006:20-1).

40. At the end of 2005, there were around 1200 specific activities for which permits were required. 
municipal agencies simply continue to administer permit systems in contravention of the law. Nevertheless, even partial implementation of the law does appear to have had a palpable positive effect: a 2006 IFC survey found that the average time spent on obtaining permits had fallen by around $30 \%$.

The next logical step in this sphere is meant to be a new law on licensing, which was submitted to parliament in the first half of 2007. The present law identifies 69 types of activity that may be subject to licensing requirements, despite the fact that it does not cover the activities most commonly subject to licensing regimes in other countries, such as financial services and telecommunications; these are dealt with in separate legislation. At present, Ukrainian law does not even contain any criteria stipulating when licensing regimes may be allowed; there is only a general statement that they should not be used to restrict competition. The need here is not only for less regulation - far too many activities are subject to licensing regimes, and new regimes are being created all the time - but also for better regulation - compliance with the terms of licences is often monitored poorly or not at all. Where licenses are deemed to be necessary, there need to be effective monitoring and enforcement mechanisms if they are to fulfil their purpose.

In this context, it is also important to highlight the large number of regulations that simply raise transaction costs and thereby reduce the efficiency of product markets. Business surveys consistently draw attention to the extraordinarily complex and cumbersome rules governing the execution and registration of transactions involving land. These are particularly burdensome for non-residents, but even Ukrainian individuals and entities find it time-consuming and costly to purchase or lease real property: in the World Bank's "Doing Business" indicators, Ukraine ranks 133rd with respect to the registration of rights to real property. ${ }^{41}$ However, on a day-to-day basis, the mandatory notarisation requirement applied to many routine transactions is likely to be even costlier to many firms. For example, the requirement that all lease agreements with terms of over one year be notarised imposes a fee equal to $1 \%$ of the value of the transaction on the contracting parties. Mandatory notarisation of a company charter likewise costs $1 \%$ of the authorised capital, which can be a substantial amount. The notarisation requirements, moreover, are symptomatic of a much larger body of rules and regulations that impose hidden charges on, and put unnecessary obstacles in the way of, perfectly ordinary transactions. The vestiges of the country's currency-control regime mean that any activities involving foreign currency cost more and take longer, and the overregulation of ordinary financial activities means that even domestic transactions, like purchases of securities and inter-company loans, are more difficult to execute. ${ }^{42}$ Over-regulation in these and other spheres does little to make the investment climate more orderly or transparent and serves mainly to distort markets, encourage shadow activity and create opportunities for official corruption.

\section{Regulatory process remains a problem}

As noted above, Ukraine's 2003 Law on the Fundamentals of Regulatory Policy is impressive on paper but has not yet been fully implemented. This weakness is reflected in a number of PMR indicators concerned with the process, rather than the substance, of regulation. Ukraine's poor score on the simplification and communication indicator (Figure A8), for example, largely reflects the lack of an integrated, explicit strategy of regulatory reform. There is no government-wide programme aimed at reducing administrative burdens on enterprises and citizens, nor does the central government even have a comprehensive picture of what these are, since it lacks a complete count of all the licences and permits required. The failure to establish systematic procedures for providing information about the enforcement or operation of regulations affects both domestic and foreign investors, who have complained about the difficulty of obtaining timely, authoritative clarifications of the meanings of particular regulations from the

41. In 2006, registering real property involved 10 distinct procedures and took an estimated average of 93 days, costing 3.4\% of the value of the property. See EBA (2006:28-41) for details of the obstacles facing non-residents; see also OECD (2004b:27-28). 
State Tax Administration and other bodies. ${ }^{43}$ Lack of information on the application and enforcement of regulations puts entrepreneurs at a particular disadvantage, given that they also lack an automatic right of non-judicial appeal in the event of adverse regulatory enforcement decisions. In short, they can fall foul of the regulator for lack of information and then be unable to appeal the decision unless they choose to litigate. Here again, the problem of regulatory uncertainty looms large - and creates opportunities for bureaucratic rent-seeking.

In other fields, it is implementation of regulatory policies that is the problem. Thus, while the framework law on regulatory policy made regulatory impact assessments (RIAs) a general requirement for all new regulatory acts, the Council of Entrepreneurs attached to the Cabinet of Ministers of Ukraine concluded in 2006 that many regulatory acts were still being promulgated without RIAs and that many of the RIAs being prepared were of poor quality and did not conform to the methodological guidelines for such assessments. Similarly, the formal requirement that regulators assess alternative policy instruments (regulatory and non-regulatory) before adopting new regulations is often breached - not least because no guidance on using alternatives to traditional regulation has ever been issued. Questions of implementation, transparency and policy process are, of course, closely interlinked, since a lack of transparency will tend to reduce the likelihood that regulatory policy processes will be observed when officials or politicians would find it more convenient to ignore them.

\section{Excessive state ownership adds to the impediments to efficient exit}

The state remains an extremely important player in the economy, not only through regulation and the provision of public goods and services, but also via its ownership of substantial productive assets. Ukraine's state-owned enterprise (SOE) sector remains fairly large, a fact that is reflected in the very high scores shown for the PMR indicators on the size and scope of the public sector (Figures A2 and A3). ${ }^{44}$ Overall, the private sector accounts for only about $65 \%$ of GDP. On the official data, roughly $48 \%$ of the country's capital stock was in the hands of the state or municipal authorities at the end of 2005, with a further $10-11 \%$ in mixed public-private ownership. Wholly private entities appear to have controlled around $41 \%$ of the capital stock. ${ }^{45}$ The latter figures reflect the extent to which the state's remaining industrial holdings are concentrated in capital-intensive sectors, such as the defence-industrial complex, heavy machine-building, the power sector and public utilities. In many cases, continued state ownership of such assets creates conflicts of interest for the authorities (particularly where the state's role as regulator is in tension with its role as owner) and serves to distort competition. Moreover, the weak corporate governance of most SOEs means that many, perhaps most, such enterprises are easy targets for rentseeking by insider-managers or well connected outsiders, be they private businessmen or officials involved in overseeing the enterprises.

The size of the SOE sector serves to limit exit and restructuring - and, in consequence, new entry. The large population of state-owned enterprises remains a drain on the budget, and well over half those transfers are subsidies to SOEs or transfers to ministries and other bodies administering subsidy

43. See EBA (2006:64-65); and Balcerowicz and Ustenko (2006:31).

44. Figure A1.4 shows that Ukraine actually ranks somewhat below the OECD average on other methods of direct control: the state owns a great deal, but it does not seek to exercise special rights over formerly stateowned enterprises via golden shares and other such mechanisms.

45. Based on Ukrstat data cited in Ekspert 48 (11-17 December) 2006 and data from the State Property Fund. This estimate is somewhat rough and ready, given the quality of data on the capital stock, but the figure is unlikely to have changed much since 2005, given the lack of privatisation and the slow rate of renewal of fixed assets. These estimates probably also reflect the presence on municipality balance sheets of a great deal of socio-cultural infrastructure transferred from enterprises to local authorities in advance of the privatisation of the former. See Friedman et al. (1997). 
programmes. ${ }^{46}$ Yet although the problems associated with the continued existence of such a large population of SOEs are widely recognised, privatisation has effectively been stalled for the last few years. The only major privatisation deal recorded in 2005 was the re-privatisation of the steel concern Kryvorizhstal, and there were no really large deals in 2006 - total privatisation income amounted to just $0.1 \%$ of GDP. Several major sales had been planned for the year but all were postponed. This is nothing new: privatisation plans are legislated annually but in recent years they have generally not been fulfilled.

\section{Overall, barriers to exit may be even more significant than restrictions on entry}

Continued support for inefficient SOEs is part of a larger problem with exit, which - perhaps surprisingly - appears on many indicators to be as difficult as entry in Ukraine. Barriers to exit impede the efficient reallocation of resources among firms and sectors and reduce the incentives for firms to restructure. In the end, of course, they constitute barriers to entry as well, since they prevent the release of production factors that might otherwise be available to new entrants. Relative both to its peers in the region and to OECD members, Ukraine fares much worse on indicators of ease of exit than it does with respect to entry. According to the World Bank, the closure of a business in Ukraine typically costs $42 \%$ of the value of the estate, as against an average of $14.3 \%$ for transition countries as a group and $7.1 \%$ for OECD members. The process leaves an average rate of recovery for creditors of just $8.7 \%$. And while it is generally faster than the transition country average (2.9 years rather than an average of 3.5 for the region), it is still very slow compared to the OECD average (1.4 years). These difficulties appear to reflect a combination of defects in bankruptcy procedures - both problems with the legislation and problems with its administration - and the tendency of the tax authorities to view any form of exit as an attempt at tax evasion. ${ }^{47}$ The tax service can tie an enterprise up for years in audits and inspections before allowing its principals to wind it up. It is symptomatic of this situation that the fees paid to intermediaries in Ukraine to wind up businesses are often far higher than those paid for starting them up, because the queues are longer and the procedures more complex.

Ukraine's current bankruptcy law, which entered into force in 2000, represents a marked improvement on its predecessor, particularly with respect to debt-restructuring procedures, the priority ordering of creditors, the protection of creditors' rights in the event of liquidation, and third-party fulfilment of debtor liabilities. ${ }^{48}$ The law also provides additional mechanisms to limit opportunities for insiders to "gamble on resurrection" 49 or to strip assets from companies that are in trouble. ${ }^{50}$ Apart from the quality of jurisprudence (many judges still lack the expertise needed to handle bankruptcy cases), the main problems that remain concern the bankruptcy of entities in which the state holds $25 \%$ or more of the equity. Since November 2001, there has been a moratorium on the mandatory disposal of the assets of such

46.

\section{World Bank (2006:41).}

This attitude is not without foundation, given the large role played by shell companies and so-called "oneday firms" in many tax avoidance schemes.

There are, however, many aspects of the law's provisions that, while broadly positive, are imprecise and therefore difficult to apply in practice; see EBA (2006:52-3)

9. If secured creditors are certain of recovering collateral, they can lend to a failing enterprise with confidence. Incumbent managers in trouble therefore borrow against assets. Managers, equity holders and "late" secured creditors thus form a coalition that may keep the enterprise afloat longer than otherwise, running up larger debts and leaving other creditors little or nothing when the firm fails.

Where companies are restructured in the context of bankruptcy proceedings, the law provides for the invalidation of obligations undertaken within six months of the approval of restructuring that involve shareholders selling their stakes or affect the priority of creditors in the event that proceedings end in liquidation. 
entities, whether inside or outside of bankruptcy proceedings. ${ }^{51}$ In theory, the moratorium is to apply only until a suitable mechanism for handling such asset disposal is devised, but no such mechanism has been created. As a result, creditors of enterprises where the state holds a blocking stake are limited in their right to recover debts via bankruptcy. This is not a merely theoretical problem: Leonov and Zhuk (2005) report that 25 companies with state shareholdings in excess of $25 \%$ went bankrupt in the first half of 2002 alone.

If a bankruptcy case ends in liquidation, the proceeds are used to satisfy the claims of creditors according to a modified version of the absolute priority rule employed in many western jurisdictions. However, the Ukrainian law gives taxes, duties and any claims of the central authorities monitoring state reserves priority over the claims of other unsecured creditors. The moratorium and the priority ordering are important issues even in cases that are unlikely to result in the winding up of the debtor firm, because the calculations of all the participants in a bankruptcy process are shaped from the outset by an awareness of their expected returns in the event of liquidation.

\section{Implicit and explicit subsidies, though declining, persist on a large scale}

Pressure to restructure or wind up many inefficient firms, in both state and private sectors, is in any case limited by the widespread, albeit declining, availability of explicit or implicit subsidies to favoured enterprises. It is difficult to assess with precision the degree of subsidy extended to particular economic sectors: comprehensive data on tax expenditures are not presented in the fiscal accounts and the extent of implicit subsidies arising from price regulation is even harder to gauge. Nevertheless it is possible to gain a rough sense of the sums involved. According to the Ministry of Finance, direct support from the state budget to industry amounted to just under 5.8 bn UAH in 2006 and is projected to rise to almost 10.7 bn in 2007 - around $1.7 \%$ of anticipated GDP. The vast bulk of this (around $75 \%$ in 2006 and $85 \%$ in 2007) consists of support for the coal industry, with the power sector accounting for most of the rest (1.1 bn UAH in both years). OECD (2007) estimates budgetary support for agriculture at 6.2 bn UAH, if both tax expenditure and direct subsidies are included.

A recent World Bank (2006) assessment estimates the ratio of tax expenditures to GDP in 2005 at $3.2 \%$, down from $7.6 \%$ in $2002 .{ }^{52}$ The abolition of tax and customs privileges for Ukraine's Free Economic Zones (SEZs) in 2005 marked an important step in curtailing inefficient tax expenditures ${ }^{53}$ and the current figure is not exceptionally large by the standards of some OECD members - tax expenditures take place on

51. In 2004, the moratorium was made retroactive to the beginning of 2000 with respect to bankruptcy cases involving mining enterprises (including coal pits, ore mines, open-cast mines, digging fields, ore-dressing plants, and coal-mining enterprises) in which the state held at least a $25 \%$ stake. Cases initiated after 1 January 2000 had to be withdrawn.

52. The sharpest reduction in tax expenditures came in 2004. It resulted from a number of factors, including: a drastic reduction in the VAT exemption on medicines (this alone cut tax expenditures on VAT by close to $1 \%$ of GDP), a similar limitation of the VAT exemption in publishing, the elimination of a number of exemptions from excise taxes, and a general tightening of the State Tax Administration's attitude towards the application of exemptions. (In addition, there were some changes to the criteria used in estimating tax expenditures, but they were not the primary factor.)

53. By 2004, roughly $10 \%$ of the territory of the country fell into designated SEZs or Priority Development Areas (TPRs). According to the Ministry of Finance, the total cost of tax breaks, exemptions and other privileges in respect of taxes, duties and other charges reached 4.7 bn UAH (about $1.4 \%$ of GDP) that year, up from 1.9 bn the year before. The figure would be substantially higher if it were possible to account for shadow activity and intra-corporate transfer pricing. During 1997-2005, the ministry estimates the tax expenditures on SEZs and TPRs at 10.5 bn UAH, over $90 \%$ of which was incurred during 2002-05. 
a very large scale in many more developed countries. ${ }^{54}$ The problem is the instability, apparent arbitrariness and distorsive effects of many of the tax privileges that have been granted in Ukraine. The implicit, quasi-fiscal subsidies extended to the rest of the economy via the mis-pricing of energy are larger - they have been estimated at a minimum of $4.3 \%$ of GDP in $2005 .{ }^{55}$

The figures outlined above do not, of course, provide a basis for assessing the total subsidy provided to any particular sector, because explicit and implicit subsidies are often cross-cutting. Many sectors (particularly energy and agriculture) receive extensive support that serves in large measure to offset the costs of other policies, such as price and trade regulation, that inflict losses on them. What the figures do illustrate, however, is the scope of the distortions created by wide-ranging state intervention in support of particular groups or sectors.

\section{The potential benefits of enhanced competition and further privatisation}

\section{Strengthening competition improves the performance of Ukrainian firms}

Closing the productivity gap between Ukraine and the more advanced economies will require increasing economic and technical efficiency - that is, the efficiency of resource allocation and the efficiency of production. ${ }^{56}$ Strengthening competition can contribute a great deal to the achievement of both these ends. Robust competition in product markets improves firm performance ${ }^{57}$ It serves to stimulate both capital deepening and technical progress. ${ }^{58}$ For transition countries, fostering competition has presented a particularly daunting challenge, not only because soft budget constraints and the suppression of competition were integral to the socialist system but also because the industrial structures bequeathed to the transition countries by central planners were often highly concentrated. Yet successful, competitionoriented reform has been rewarded: where post-communist reformers were more successful in fostering competition, performance has tended to improve. ${ }^{59}$ In the case of Russia, in particular, recent studies have found a positive correlation between competition and total factor productivity growth. ${ }^{60}$

54. Comprehensive data are not available, because many countries do not account for tax expenditures systematically; however, the US Government Accountability Office estimates the sum of tax expenditure outlay estimates at around 7.5\% of GDP for 2004 (GAO, 2005), while the Australian Treasury gives a figure of about $4 \%$ for 2005 (Treasury, 2005).

55. The figure could run as high as $9.8 \%$ of GDP, depending on the "market" price of gas used: the lower estimates use the average price of independent gas traders in Ukraine as the benchmark, whereas the higher use the regional market price. See World Bank (2006:63).

56. Both forms of efficiency are important: a monopoly, for example, may be technically efficient (operating at, rather than below, its production function) but not allocatively efficient. Allocative efficiency is best served by robust competition.

57. See, e.g., Aghion and Griffith (2005); or Conway et al, (2006).

58. Nicoletti and Scarpetta (2005).

59. See, e.g., EBRD (2002); Carlin et al. (2001); Vagliasindi (2001).

60. See OECD (2006a) and Aghion and Bessonova (2006). 
The potential benefits of increasing competition are likely to be even larger in Ukraine than in most OECD members or in many neighbouring countries, because competition in Ukrainian markets, though increasing in recent years, is relatively weak overall. To a significant extent, this reflects the large number of important Ukrainian sectors that are highly concentrated and characterised by a substantial degree of monopoly or by oligopolistic competition. ${ }^{61}$

There has been only limited empirical work on the relationship between competition and enterprise performance in Ukraine, apart from a few cross-national studies in which it has been included ${ }^{62}$ This section therefore presents the findings of an econometric analysis of the impact of competition on labour productivity gains based on enterprise-level data drawn from the official register of industrial enterprises for 2000-05. The empirical model is described in detail in Annex C: the model essentially tests the effect of the degree of concentration in the regional market on the growth of real labour productivity at the firm level. The theoretical framework underlying this analysis is developed in Aghion et al. (2004, 2005). These studies find, first, that reducing barriers to entry, particular to foreign products, has a positive effect on economic performance and, secondly, that the effect is particularly strong for firms and industries that are initially closer to the technology frontier. In contrast, performance in firms and industries that are initially far from the frontier may actually be damaged by liberalisation and greater competition. Therefore, the distance to the technology frontier is added as an explanatory variable. Finally, the analysis explicitly takes into account the impact of foreign trade operations and competition from foreign producers via the introduction of the import penetration ratio into the regression. The following conclusions emerge (see Table 5):

- Concentration, measured by the 5 digit HHIs, has a negative and highly significant impact on labour productivity growth.

- These results are robust for manufacturing as a whole, and there is evidence that the effect is stronger when import- or export-competing industries are considered separately.

- For market services, the effect is found to be weaker (and less significant) but still sizeable.

- Import competition has a positive impact on domestic firms' productivity. The effect is stronger in sectors where foreign penetration is lower, which may suggest that the initial opening to imports has a particularly strong effect in stimulating local firms to raise productivity. ${ }^{63}$

- The effect of the distance to frontier and the distance to frontier interacted with the degree of concentration is on the other hand less clear cut.

61. See, e.g., AMCU (2006); IERPC (2003, 2006); NTK (2006); Stotyka (2004); and Akimova and Shcherbakov (2002).

62. For one important exception, see Akimova and Shcherbakov (2002), who focus exclusively on technical efficiency (x-efficiency). It should be noted that they fail to find strong evidence of the benefits of competition for technical efficiency in Ukraine, but their analysis does not take account of import competition; as will be seen, the impact of trade openness in some Ukrainian sectors is critical. See also Chernenko (2004) for the evidence presented by the AMCU to the OECD's 2004 Global Forum on Competition, and Blue Ribbon (2006:47-8). IERPC (2003) looks closely at a few key sectors but stops short of an empirical analysis of the impact of competition on performance.

63. It may also simply reflect the outcome of competition: where local firms respond rapidly and effectively to import competition, they are more likely to retain market share. 
ECO/WKP(2007)34

Table 5. Labour productivity regressions

\begin{tabular}{|c|c|c|c|c|}
\hline \multirow{2}{*}{$\begin{array}{c}\text { Dependent variable } \\
\text { Real labour } \\
\text { productivity growth }\end{array}$} & \multicolumn{3}{|c|}{ Manufacturing industries } & \multirow{2}{*}{$\begin{array}{c}\text { Market } \\
\text { services }\end{array}$} \\
\hline & $\begin{array}{c}\text { All } \\
\text { manufacturing }\end{array}$ & $\begin{array}{l}\text { Export } \\
\text { oriented }\end{array}$ & $\begin{array}{l}\text { Import } \\
\text { competing }\end{array}$ & \\
\hline$H H I$ & $\begin{array}{l}-0.18^{* * *} \\
(-7.23)\end{array}$ & $\begin{array}{l}-0.28^{\star * \star} \\
(-5.32)\end{array}$ & $\begin{array}{l}-0.29^{\star \star \star} \\
(-5.22)\end{array}$ & $\begin{array}{c}-0.15^{\star} \\
(-1.94)\end{array}$ \\
\hline Import penetration & $\begin{array}{l}-0.00 \\
(-0.08)\end{array}$ & $\begin{array}{l}0.11^{\star *} \\
(2.01)\end{array}$ & $\begin{array}{c}0.11^{*} \\
(1.83)\end{array}$ & \\
\hline Distance to frontier ${ }^{1}$ & $\begin{array}{l}-0.01^{* * *} \\
(-3.29)\end{array}$ & $\begin{array}{c}0.01^{*} \\
(1.85)\end{array}$ & $\begin{array}{l}0.05^{\star \star \star} \\
(4.31)\end{array}$ & $\begin{array}{l}0.07^{\star \star \star} \\
(4.55)\end{array}$ \\
\hline$H H{ }^{*}$ distance to frontier & $\begin{array}{c}0.01 \\
(1.16)\end{array}$ & $\begin{array}{c}0.01 \\
(0.58)\end{array}$ & $\begin{array}{l}-0.04^{*} \\
(-1.78)\end{array}$ & $\begin{array}{l}-0.05^{\star} \\
(-1.96)\end{array}$ \\
\hline Year dummies & yes & yes & yes & yes \\
\hline Number of jobs & 102215 & 30315 & 22889 & 14438 \\
\hline Number of firms & 39248 & 16493 & 11388 & 8813 \\
\hline
\end{tabular}

Fixed effects estimations.

t-statistics in parenthesis.

* significant at $10 \%$ level; ${ }^{* *}$ significant at $5 \%$ level; ${ }^{* * *}$ significant at $1 \%$ level.

1. Distance to frontier is computed as the difference between the highest productivity in the sector and firm's productivity.

Source: OECD calculations using the register of Ukrainian enterprises, 2000-05.

\section{Privatisation promotes efficiency and productivity growth}

The size of the state has been identified in this paper as another key barrier to growth: substantial public subsidies introduce distortions between sectors and excessive state ownership hampers the process of restructuring and reallocation of resources. ${ }^{64}$ In these circumstances, the loss of privatisation momentum is unfortunate: after peaking in 2005 at $5.1 \%$ of GDP, privatisation receipts in 2006 were minimal $(0.1 \%)$. Early 2007 saw signs of increased privatisation activity, but it is not clear where this might lead. The government's medium-term fiscal plan contains ambitious targets for privatisation income, equivalent to roughly 10 bn UAH (around 1.9\% of estimated 2006 GDP) per year over 2007-09, and the authorities have expressed an interest in selling large parts of the fixed-line telephone monopolist Ukrtelekom, a number of regional energy companies (so-called oblenergos) and the Odessa Portside Plant, which is among the country's largest producers of ammonia and nitrogen fertilisers. It is far from clear how these plans will work out in practice. Actual privatisation activity remains highly non-transparent, ${ }^{65}$ and political turmoil has raised questions about whether or when the next big privatisations will take place. ${ }^{66}$ The most recent major privatisation - the long-delayed sale of $76 \%$ of Luganskteplovoz, a producer of locomotives and trams, for $\$ 57.9 \mathrm{~m}$ in March 2007 - was a fairly opaque process that resulted in a sale price that was just $0.17 \%$ above the starting price for the stake. The president has ordered an investigation of the sale, which is now being challenged in the courts. ${ }^{67}$

64. The restructuring of SOEs themselves is hampered by protective legislation on bankruptcy procedures described and, in the case of many privatisations, by potentially constraining social clauses, concerning job preservation and other conditions pertaining to the post-privatisation management of the company.

65. The second Kryvorizhstal sale remains an exceptional case in this respect.

66. On 14 May, the government suspended the privatisations of stakes in Ukrtelekom and the Odessa Portside Plant, citing the ongoing political crisis. On 22 May, a court ruling blocked an attempt to sell even a $1 \%$ stake in Ukrtelekom in order to test the market.

67. It has been alleged that eligible bidders were excluded from the auction and that the two firms admitted to participate ultimately represented the same beneficial owner. 
Ukraine's stalled privatisation process is particularly regrettable in view of mounting evidence that privatisation in Ukraine has improved enterprise productivity and efficiency. ${ }^{68}$ The defects of Ukrainian privatisation processes cannot be denied and account for much of the criticism of privatisation within the country, but they should not deflect attention from empirical work pointing to the positive impact of privatisation on sales growth and profitability. ${ }^{69}$ Using panel data on Ukrainian firms for 1996-2000, Andreyeva (2003) estimates a production function using random-effects and instrumental variable estimators. She finds evidence that firm performance improves significantly with privatisation, particularly when it results in the concentration of ownership in the hands of a dominant shareholder. A large study conducted in 2004 on behalf of the State Property Fund found that privatised enterprises reduced wage arrears faster, innovated more, invested more efficiently and increased productivity and output more rapidly than did state-owned enterprises. ${ }^{70}$ According to Zelenyuk and Zheka (2006), better performance is partly the product of better corporate governance of private companies, which leads in turn to greater technical efficiency. Interestingly, Grygorenko and Lutz (2007) find that there is a non-trivial positive relationship between state ownership and enterprise performance in enterprises that are majority privately owned but that the relationship between state ownership and performance is strongly negative where the state share exceeds 50\%. ${ }^{71}$ This suggests that privatised firms in which the state still holds shares may yet profit from explicit or implicit subsidies and/or regulatory forbearance on the part of the authorities.

While these and other studies converge in their conclusion that privatisation has positive effects on firm performance, quantifying those effects is still on the research agenda. Using a rich longitudinal database on Ukrainian manufacturing firms, Brown and Earle (2007b) provide an assessment of the productivity effects of privatisation over time. The long time series, which extends from 1989 until 2005, enables them to include several years of pre-privatisation data and to control for potential selection bias in the privatisation process. For privatisation to domestic owners, they find that total factor productivity increased between 10 and $25 \%$, depending on the specification used, during the seven years following privatisation. They find the effect of foreign privatisation to be even stronger, but the estimates are less robust owing to the sample size. ${ }^{72}$ Positive effects appear within a year of privatisation and continue increasing thereafter (Figure 5). Given that the privatisation process was still relatively intense in the late 1990s and even the early 2000s, this implies that the contribution of privatisation to aggregate manufacturing productivity growth in recent years has been substantial - the cumulative contribution reaches 20 to $40 \%$, according to the specification used.

Despite widespread fears that privatisation would lead to job losses, Brown, Earle and Vakhitov (2006) find that privatisation reduces worker separations (both quits and dismissals) substantially. This comes at a price, however: privatisation is also associated with lower wage levels - ironically, with the largest wage losses coming in worker-controlled firms. Outsider-controlled firms enjoy wage gains. Of

68. Akimova and Schwödiauer (2003) are the main exception to this rule: they do not report a strong result for private vs. state ownership; however, their study focuses on the structure of ownership of privatised enterprises (insider, outsider Ukrainian, foreign, residual state) rather than on privatisation per se.

69. It would, of course, be a mistake to conclude that privatisation processes are not important: the manner in which privatisations are conducted can affect the extent to which, and the speed at which, the benefits of privatisation are realised.

70. See Dubrovskiy et al. (2004), especially the conclusions presented at pp. 141ff.

71. Pivovarsky (2003) also finds that majority state ownership has a statistically significant negative effect on total factor productivity. The coefficient for state ownership under $50 \%$ is negative but not significant.

72. The effect is found to be twice as high in the short run, but also weakening in the long-run for some specifications of the empirical model used. 
Figure 5. Multi-factor productivity impact of privatisation

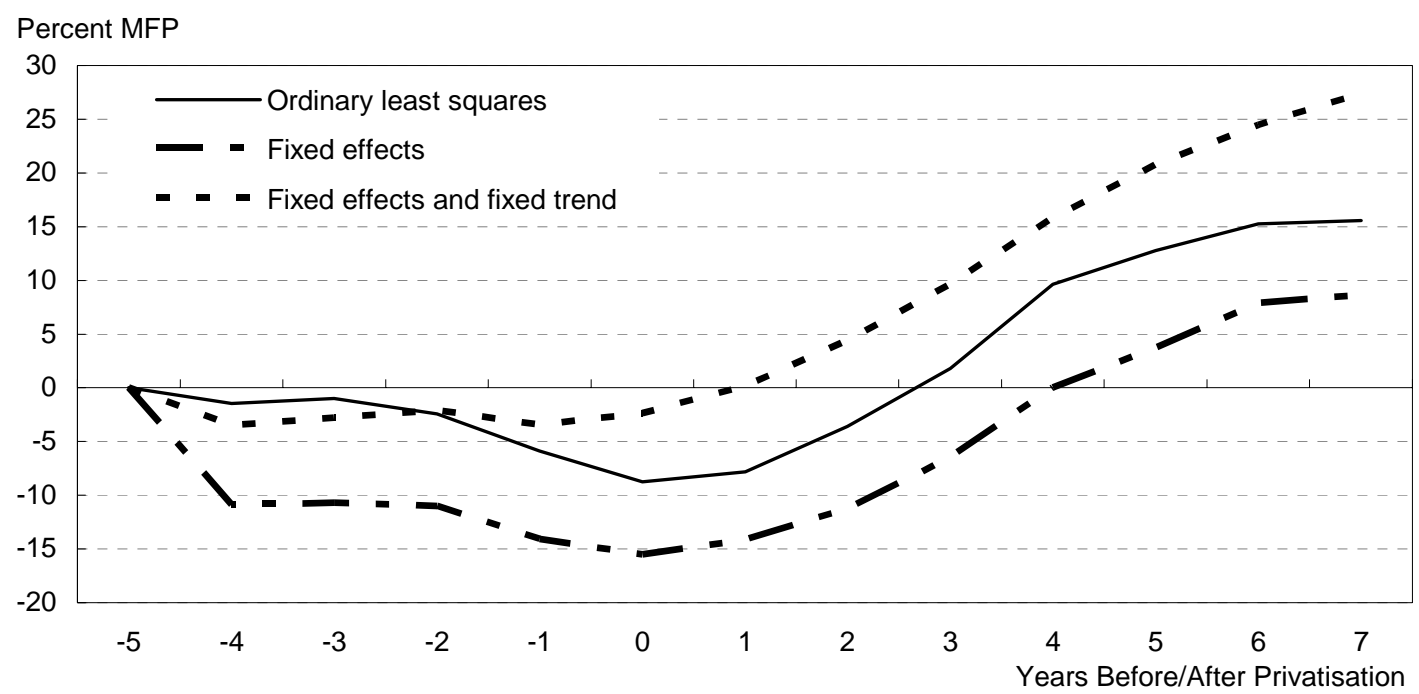

Source: Brown and Earle (2007b).

course, privatisation has been associated with labour-shedding - employment in Ukrainian industry has fallen by almost half since the transition began, and privatised enterprises account for a large part of the reduction. However, it appears that privatisation and restructuring offer better prospects for preserving more jobs over the medium-to-long term.

Despite widespread fears that privatisation would lead to job losses, Brown, Earle and Vakhitov (2006) find that privatisation reduces worker separations (both quits and dismissals) substantially. This comes at a price, however: privatisation is also associated with lower wage levels - ironically, with the largest wage losses coming in worker-controlled firms. Outsider-controlled firms enjoy wage gains. Of course, privatisation has been associated with labour-shedding - employment in Ukrainian industry has fallen by almost half since the transition began, and privatised enterprises account for a large part of the reduction. However, it appears that privatisation and restructuring offer better prospects for preserving more jobs over the medium-to-long term.

These findings clearly point to the potential benefits of further privatisation. However, in some specific sectors or market segments characterised by a substantial degree of natural monopoly, privatisation entails the need to develop new forms of economically efficient regulation, as well as preliminary steps to ensure the development of real competition. ${ }^{73}$ Ownership change does not necessarily achieve much if undertaken without due attention to market structure and potential competition. However, there is more to the competition-privatisation relationship than simply a pitfall to be avoided in some complex sectors. There are also potentially beneficial synergies: theory suggests that the benefits of privatisation are likely to be greater if combined with regulatory and other reforms aimed at strengthening competition, and a large and growing body of empirical research suggests that this is indeed the case. Research in developed market economies, developing countries and economies in transition finds that private enterprises generally respond more readily to increasing competitive pressures than do SOEs, and 
the gains from privatisation tend to be greater where privatised enterprises are subject to competition. ${ }^{74}$ Effective private ownership and competition are thus mutually reinforcing devices for disciplining managers and giving them incentives to restructure. In a weak institutional environment, moreover, the complementarity between the two may be all the greater, since competition can sometimes help offset other institutional weaknesses. ${ }^{75}$

74. On the complementarities between privatisation and competition, see Megginson and Netter (2001); Commander et al. (1999); and the work surveyed in Nellis (1998). In an enterprise-level study covering Bulgaria, Romania and Poland, Angelucci et al. (2002) find that competitive pressure has stronger effects on the productivity of privatised firms, as do Earle and Estrin (2003) in Russia. On Mexico, see La Porta and Lopez-de-Silanes (1997).

75. See Commander et al. (1999:10). Where shareholder and creditor monitoring is weak and ownership is dispersed, robust product-market competition can increase the external pressure for more efficient management, by increasing the sensitivity of profits to unit costs, while at the same time reducing agency losses within the firm, by compelling managers to pay more attention to profit maximisation. 


\section{BIBLIOGRAPHY}

“About natural monopolies" (2005), "Law of Ukraine "About Natural Monopolies", as amended by law No. 2599-IV, 31 May, available at www.lexadin.nl/wlg/legis/nofr/oeur/lxweukr.htm

Aghion, P., C. Harris, P. Howitt and J. Vickers (2001), "Competition, Imitation and Growth with Stepby-Step Innovation”, Review of Economic Studies, 68:3.

Aghion, P., N. Bloom, R. Blundell, R. Griffith and P. Howitt (2005), "Competition and Innovation: An Inverted U Relationship", Quarterly Journal of Economics 120:2, May.

Aghion, P. and R. Griffith (2005) Competition and Growth. Reconciling Theory and Evidence, Cambridge, MA, The MIT Press.

Aghion, P. and E. Bessonova (2006), "On Entry and Growth: Theory and Evidence", Revue de l'OFCE 97 bis 2006/3, June.

Aghion, P. and P. Howitt (2006), “Appropriate Growth Policy: A Unifying Framework”, Journal of the European Economic Association 4:2-3, April-May, available at www.mitpressjournals.org/doi/pdf/10.1162/jeea.2006.4.2-3.269.

Akimova, I. and A. Shcherbakov (2002), "Competition and Technical Efficiency of Ukrainian Manufacturing Enterprises", Institute for Economic Research and Policy Consulting Working Paper No. 17, October, available at http://ierpc.org/ierpc/wp/WP_17_eng.pdf.

Akimova, I. and G. Schwödiauer (2003), "Trust in Commercial Courts and Its Effect on the Performance of Ukrainian SMEs", Institute for Economic Research and Policy Consulting Working Paper No. 23, December, available at www.ier.kiev.ua/English/WP/2003/wp_23_eng.pdf.

Alesina, A., S. Ardagna, F. Schiantarelli and G. Nicoletti (2003), "Regulation and Investment", NBER Working Papers, No. 9560.

AMCU (2006), "Konkurentsiya v Ukraini: Analitchna dopovid' shchodo stanu, tendentsiy i problem rozvitku ekonomichnoi konkurentsii v Ukraini u 2000-2005 rokakh", Kyiv, Anti-Monopoly Committee of Ukraine, available at www.amc.gov.ua/amc/doccatalog/document?id=47018.

Andreyeva, T. (2003), "Company Performance in Ukraine: What Governs Its Success", EERC Working Paper 03/01, available at www.eerc.ru/details/download.aspx?file_id=3726.

Angelucci, M., S. Estrin, J. Konings and Z.Zolkiewski (2002), "The Effect of Ownership and Competitive Pressure on Firm Performance in Transition Countries: Micro Evidence from Bulgaria, Romania and Poland", William Davidson Institute Working Paper No. 434, January,

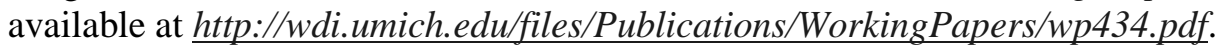


Arnold, J., B. Javorcik and A. Mattoo (2007), "Does Services Liberalization Benefit Manufacturing Firms? Evidence from the Czech Republic", World Bank Policy Research Working Paper No. 4109, January, available at www-wds.worldbank.org/external/default/WDSContentServer/ IW3P/IB/2007/01/09/000016406_20070109095012/Rendered/PDF/wps4109.pdf.

Balcerowicz, E. and O. Ustenko (2006), "Regulatory Policy in Ukraine: Current State and What Should be Done to Improve the Business Environment", Studies and Analyses 324, Warsaw, CASE, April, available at www.case.com.pl/upload/publikacja plik/10822499 sa324.pdf.

Blue Ribbon (2006), The State and the Citizen: Delivering on Promises, Kyiv, UNDP Blue Ribbon Commission for Ukraine, 12 December.

Brown, J. and J. Earle (2004), "Job Reallocation and Productivity Growth in the Ukrainian Transition", Upjohn Institute Staff Working Paper 04-104, November, available at www.upjohninst.org/publications/wp/04-107.pdf.

Brown, D., J. Earle and V. Vakhitov (2006), "Wages, Layoffs and Privatization: Evidence from Ukraine", Upjohn Institute Working Paper 06-126, February, available at www.upjohninstitute.org/publications/wp/06-126.pdf.

Brown D. and J. Earle (2007a), "Competitive Pressure and Productivity Growth in Ukraine", Background paper prepared for the 2007 OECD Economic Policy Seminar on Ukraine, May.

Brown, J. and J. Earle (2007b), "The Productivity Effects of Privatization in Ukraine: Estimates from comprehensive Manufacturing Firm Panel Data, 1989-2005”, Background paper prepared for the 2007 OECD Economic Policy Seminar on Ukraine, May.

Carlin, W., S. Fries, M. Schaffer and P. Seabright (2001), "Competition and Enterprise Performance in Transition Economies: Evidence from a Cross-Country Survey", EBRD Working Paper No. 63, June, available at www.ebrd.com/pubs/econo/wp0063.pdf.

Chernenko, S. (2004), "How Enforcement against Private Anticompetitive Conduct has Contributed to Economic Development", Contribution from Ukraine to the OECD Global Forum on Competition, 27 January.

Commander, S., M. Dutz and N. Stern (1999), "Restructuring in Transition Economies: Ownership, Competition and Regulation", Paper prepared for the Annual World Bank Conference on Development Economics, Washington, DC, 28-30 April, available at http://siteresources.worldbank.org/INTABCDEWASHINGTON1999/Resources/stern.pdf.

Conway, P., V. Janod and G. Nicoletti (2005), "Product Market Regulation in OECD Countries: 1998 to 2003", OECD Economics Department Working Papers, No.419, 1 April, available at www.olis.oecd.org/olis/2005doc.nsf/linkto/ECO-WKP(2005)6.

Conway, P., D. de Rosa, G. Nicoletti and F. Steiner (2006), "Regulation, Competition and Productivity Convergence", OECD Economics Department Working Papers, No. 509, 4 September, available at www.olis.oecd.org/olis/2006doc.nsf/linkto/ECO-WKP(2006)37.

Davis, S. and J. Haltiwanger (1992), "Gross Job Creatioçn, Gross Job Destruction and Employment Reallocation”, Quarterly Journal of Economics, Vol.107:3, August. 
"Derzhavna" (2006), Derzhavna reestratsiya sub"ektiv hospodaryuvannya: doslizhdennya protsedur derzhavnoi reestratsii ta novi normatyvno-pravovi akty: Dovidnyk, Kyiv, Blue Ribbon Analytical Centre of the UN Development Programme and State Committee for Regulatory Policy and Entrepreneurship.

Dubrovskiy, V., T. Shygaeva, A. Belotserkovets, R. Bondarenko and N. Golovanenko (2004), "Zvit po rezul'taty doslizhden' po proektu 'Sotisal'no-ekonomichni naslidky pryvatizatsii derzhavnogo mayna v Ukraini: pershi desyat' rokiv", Kyiv, CASE Ukraine.

Earle, J. and S. Estrin (2003), "Privatization, Competition and Budget Constraints: Disciplining Enterprises in Russia", Economics of Planning 36:1.

EBA (2006), Barriers to investment in Ukraine, Kyiv, European Business Association, May, available at www.eba.com.ualfiles/Investment paper/Barriers to Investment in Ukraine Apr 2006 ENG print.pdf.

EBRD (2002), Transition Report 2002, London, European Bank for Reconstruction and Development.

Ernst, M., M. Alexeev and P. Marer (1995), Transforming the Core: Restructuring Industrial Enterprises in Russia and Central Europe, Boulder, CO, Westview Press.

Friedman, B., M. Rein and A. Wörgötter (1997), Social Benefits after Communism: The Role of the Enterprises, Cambridge and London, Cambridge University Press.

GAO (2005), "Tax Expenditures Represent a Substantial Federal Commitment and Need to Be Reexamined", Washington, DC, US Government Accountability Office, September, available at www.gao.gov/new.items/d05690.pdf.

Gazizullin, I. (2006a), "Back to the Drawing Board: Restructuring Ukraine's Network Industries", INDEUNIS Papers, March, available at http://indeunis.wiiw.ac.at/index.php?action=content\&id=wp2.

Grygorenko, G. and S. Lutz (2007), "Firm Performance and Privatization in Ukraine", Economics Discussion Paper EDP0704, University of Manchester, February, available at www.socialsciencesmanchester.ac.uk/economics/research/discuss.htm.

ICS (2006), Shchodo gotovnosti pidpriemnitskoi spil'noty vplyvaty na rishennya organiv derzhavnoi vlady, Kyiv, Institute for a Competitive Society.

IEA (2006), Ukraine: Energy Policy Review 2006, Paris, International Energy Agency.

IERPC (2003), "Development of Domestic Markets in Ukraine: Welfare through Competition”, Kyiv, Institute for Economic Research and Policy Consulting, May, available at www.ier.kiev.ua/English/books/dev_of_dom_eng.pdf.

IERPC (2006), "Enterprise Survey: Business Climate and Investment, 2005-06”, Quarterly Enterprise Survey 3:6, Kyiv, Institute for Economic Research and Policy Consulting, October, available at www.ier.kiev.ua/English/qes/special qes6 eng.pdf. 
La Porta, R. and F. Lopez-de-Silanes, (1997), "The Benefits of Privatization: Evidence from Mexico", NBER Working Paper No. 6215, October.

Leonov, D. and R. Zhuk (2005), "Study on Management of State-Owned Enterprises in Ukraine," Kyiv, Ukrainian Stock Market Development Institute.

Megginson, W. and J. Netter (2001), "From State to Market: A Survey of Empirical Studies on Privatization", Journal of Economic Literature 39:2, June, available at http://faculty-staff.ou.edu/M/William.L.Megginson-1/prvsvpapJLE.pdf.

Nellis, J. (1998), “Time to Rethink Privatization in Transition Economies?” International Finance Corporation Discussion Paper No. 38, available at http://ifcln1.ifc.org/ifcext/economics.nsf/AttachmentsByTitle/dp38/\$FILE/dp38.pdf.

Nicoletti, G. and S. Scarpetta (2003), "Regulation, Productivity and Growth: OECD Evidence", Economic Policy, No. 36:1, April.

Nicoletti, G. and S. Scarpetta (2005), "Regulation and Economic Performance: Product Market Reforms and Productivity in the OECD”, OECD Working Papers No. 460, available at www.olis.oecd.org/olis/2005doc.nsf/linkto/ECO-WKP(2005)47.

NTK (2006), "Stan dilovoi aktyvnosti promyslovykh pidpriemstv Ukrainy u III kb. 2006r.", Kyiv, Scientific and Technical Complex for Statistical Research of the State Committee for Statistics, available at www.ntkstat.kiev.ua/nedos3.06.htm

OECD (2004a), OECD Economic Surveys, Russian Federation, Paris, OECD.

OECD (2004b), "Legal Issues with Regard to Business Operations and Investment in Ukraine", Paris, OECD, September, available at http://en.logisticsplatform.com.ualfiles/Legal\%20Issues\%20with\%20regard\%20to\%20Business \%200perations\%20and\%20Investment\%202004\%20Eng.pdf.

OECD (2006a), "Roundtable on Enterprise Development and Investment Climate in Ukraine”, OECD, Paris, 13 June, available at www.oecd.org/dataoecd/26/16/37051201.pdf.

OECD (2006b), OECD Economic Surveys, Russian Federation, Paris, OECD.

OECD (2007a), OECD Economic Surveys: Ukraine: Economic Assessment, Paris, OECD.

OECD (2007b), Agricultural Policies in Non-OECD Countries. Monitoring and Evaluation, Paris, OECD.

Paskhaver, A. and L. Verkhovodova (2005), "Privatizatsiya do i posle oranzhevoi revolyutsii", CASE Studies and Analyses No. 319, March.

Pivovarsky, A. (2003), "Ownership Concentration and Performance in Ukraine's Privatized Enterprises", IMF Staff Papers 50:1, April, available at www.imf.org/External/Pubs/FT/staffp/2003/01/PDF/Pivov.pdf.

Scarpetta, S., P. Hemmings, T. Tressel and J. Woo (2002), "The Role of Policy and Institutions for Productivity and Firm Dynamics: Evidence from Micro and Industry Data", OECD Economics 
Department Working Papers, No.329, 23 April, available at www.olis.oecd.org/olis/2002doc.nsf/linkto/eco-wkp(2002)15.

"Shchodo" (2006), "Shchodo pereglyadu regulyatornykh aktiv", State Committee for Questions of Regulatory Policy and Entrepreneurship, 26 January, available at www.business-rada.kmu.org.ua/ua/news/337.htm.

Shumylo, I. (2007), "Kakova pravda ob ekonomicheskom roste v Ukraine?", Zerkalo nedeli, 19:648, 19-25 May.

Stotyka, Y. (2004), "The Role of the Anti-Monopoly Committee in the Development of Competition in Ukraine", Amsterdam, Tinbergen Institute, August, available at http://ssrn.com/abstract $=613262$.

Treasury (2005), "Tax Expenditures Statement 2005", Canberra, The Treasury, 21 December, available at $h t t p: / /$ treasury.gov.au/documents/1052/PDF/TES_2005.pdf.

Vagliasindi, M. (2001), "Competition across Transition Economies: An Enterprise-Level Analysis of the Main Policy and Structural Determinants", EBRD Working Paper No. 68, December.

World Bank (2006a), "Ukraine: Creating Fiscal Space for Growth: A Public Finance Review", Washington, DC, The World Bank, 14 September, available at http://siteresources.worldbank.org/INTUKRAINE/Resources/3283351158937917927/UkrainePFRFinalEng.pdf.

Zelenyuk, V. and V. Zheka (2006), "Corporate Governance and Firm's Efficiency: The Case of a Transitional Country, Ukraine”, Journal of Productivity Analysis 25:1. 


\section{ANNEX A \\ Product-market regulation in Ukraine}

As noted in the main text of the paper, product-market competition is a key driver of productivity growth in OECD countries. ${ }^{1}$ To gauge the extent of restrictions on competition in product markets and identify weaknesses in regulatory frameworks, the OECD Economics Department has constructed a set of quantitative indicators of product-market regulation (PMR). PMR assessments are systematically done for all member economies, and they have been conducted for a small but increasing number of non-members as well. They provide a basis for assessing countries' performance in a comparative context. The ability to benchmark current regulation and future policy choices in this manner is an important element of the OECD "peer review" of economic policies and has proven useful in encouraging countries to implement structural reforms that can enhance economic performance.

\section{Overview of the PMR system}

The PMR indicator system has a pyramidal shape, with 16-low-level indicators at the base, three intermediate-level aggregate indicators in the middle and one overall indicator of the degree of product-market regulation at the apex (Figure A1.1). The low-level indicators capture specific aspects of the regulatory regime, summarising information on government responses to more than 140 questions concerned with economy-wide or industry-specific regulatory provisions. They reflect regulatory policy settings as of end-March 2007; in some instances, changes have been adopted since then but it has not been possible to recalculate the indicators. The intermediate-level aggregate indicators and the overall PMR indicator are constructed as weighted averages of their constituent lower-level indicators. ${ }^{2}$ The low-level and intermediate indicators are divided into two main groups: those concerned with inward-oriented policies, comprising state control and barriers to entrepreneurship; and those focusing on outward-oriented policies, comprising barriers to trade and investment.

The 16 low-level indicators in the PMR system cover a wide range of product market policies. This annex provides a brief description of each low-level indicator, the benchmarking of Ukraine against OECD members with respect to that indicator and, where necessary, commentary on the interpretation of the results for Ukraine. (The OECD data reflect the most recent PMR exercise, conducted in 2003.) First, however, it is necessary to comment briefly on what the PMR indicators do and do not cover.

1.

See OECD (2002), Nicoletti and Scarpetta (2003); Conway et al. (2005); and Conway et al. (2006) for empirical evidence on the links between the intensity of competition in product markets and productivity performance.

2. See Conway et al. (2005) for more detailed information on the content of the regulatory questionnaires, the methodology used to construct the low-level indicators and the aggregation of the summary indicators. 
- The indicators are designed to reflect regulations that have the potential to reduce the intensity of competition in areas of the product market where technology and market conditions make competition viable; they are, therefore, of greater direct relevance to some sectors than others. However, some of the indicators capture aspects of regulatory institutions and procedures that, if deficient, may reduce the overall quality of regulation: these are likely to be relevant to virtually all sectors. 

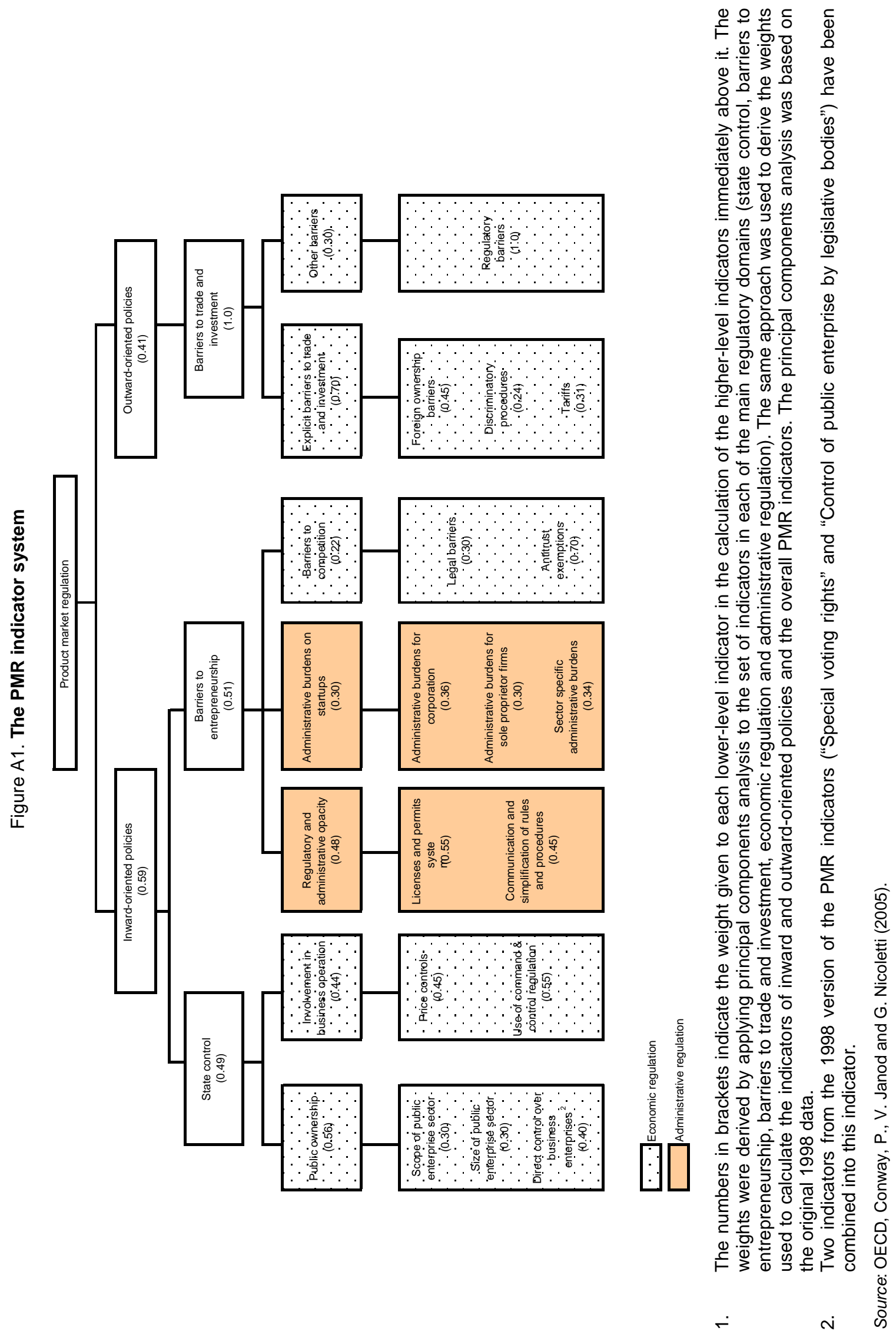
- As noted in the main text, the indicators are based on explicit policy settings and thus reflect formal regulation only. "Informal" regulatory practices, such as administrative guidance or self-disciplinary measures of professional associations, are captured to only a very limited extent in the PMR indicators system. Similarly, the way in which regulations are applied by enforcement authorities, which can have an enormous impact on competition in a given market, is also only reflected to a very limited degree in the PMR indicators.

- The indicators are designed to facilitate broad comparisons among OECD members and to some extent their construction reflects norms, practices and institutional characteristics more typical of OECD members. In some cases, therefore, individual indicators may have a tendency to generate surprisingly favourable or unfavourable scores for emerging economies.

\section{Results of the PMR assessment of Ukraine}

The scope of public enterprise indicator measures the pervasiveness of state ownership across business sectors. It reflects the proportion of major sectors in which the state holds an equity stake in at least one firm.

Figure A2. Scope of public enterprise

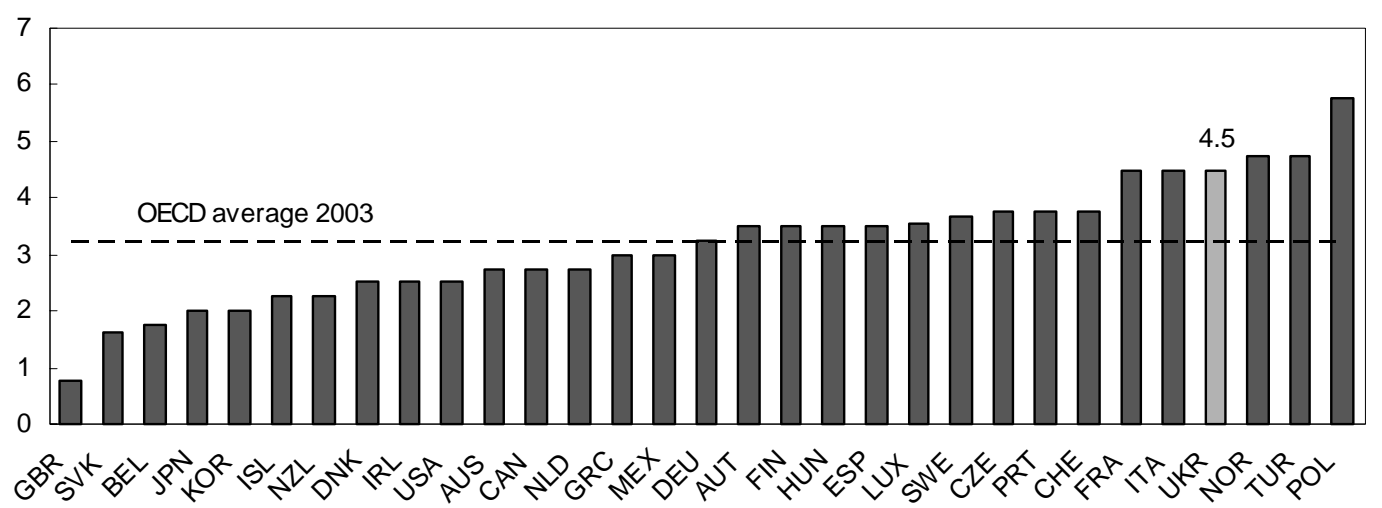

The indicator for the size of public enterprise reflects the overall size of the state-owned enterprise (SOE) sector relative to the size of the economy as a whole.

Figure A3. Size of public sector

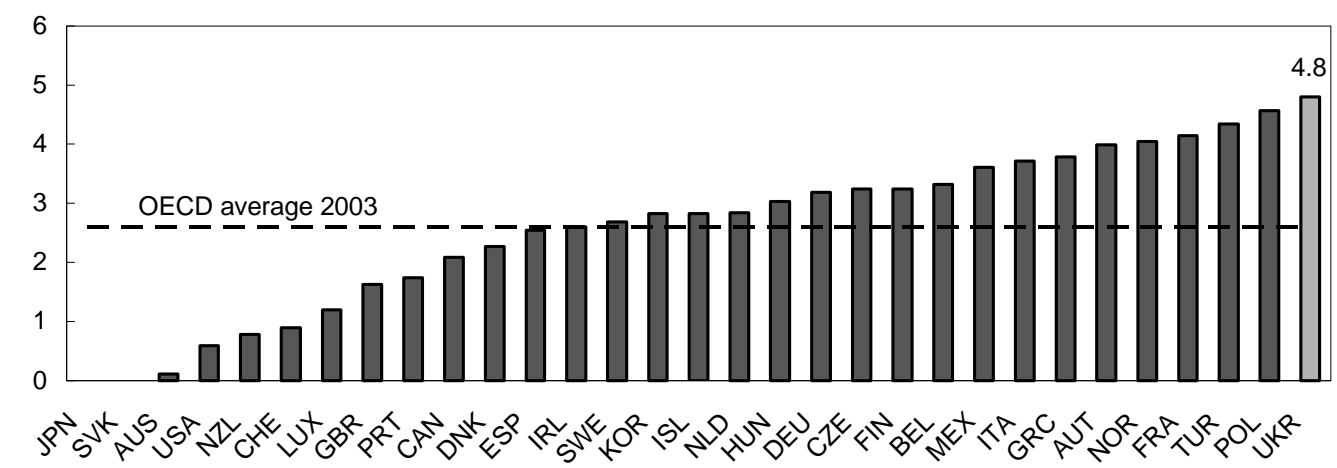


Direct control over business enterprises measures the existence of government special voting rights in privately owned firms, constraints on the sale of state-owned equity stakes, and the extent to which legislative bodies control the strategic choices of public enterprises. Ukraine's low score on this indicator is in part a product of its high score on the scope and size of the public sector: the authorities prefer to exercise control via ownership stakes rather than the assertion of special rights (such as golden shares, which do not exist in Ukraine). Moreover, the role of the legislative branch is relatively limited: the SOE sector is overseen by the executive.

Figure A4. Direct control over business enterprises

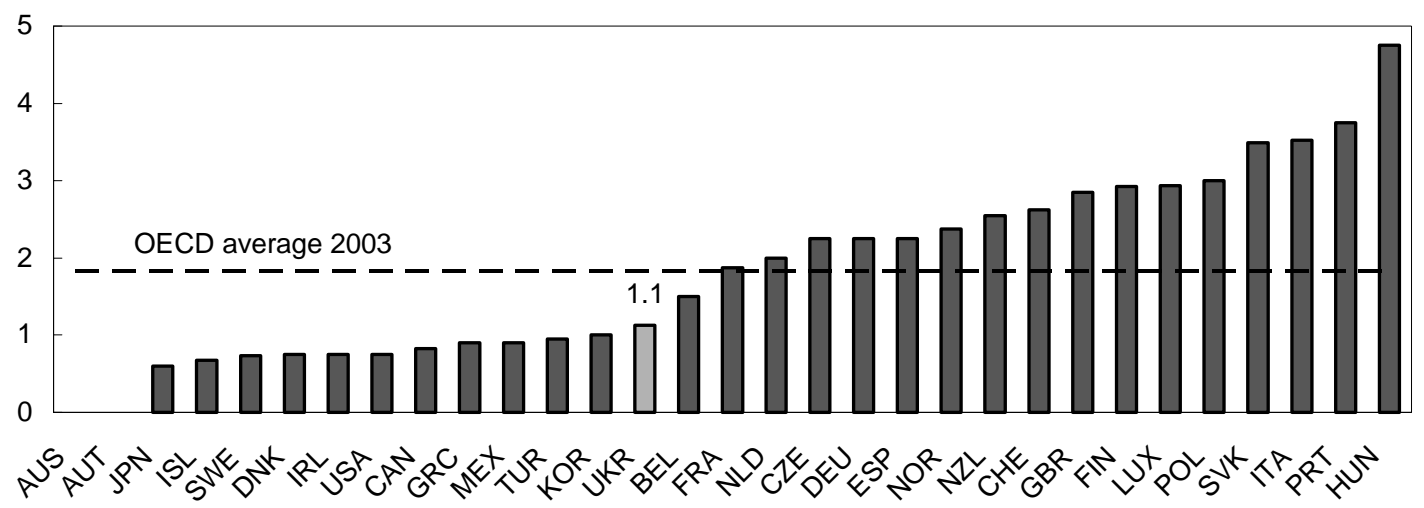

The price controls indicator reflects the extent of price controls in specific sectors. Ukraine's results in this instance are greatly affected by the construction of the indicator. The indicator looks at a range of sectors commonly subject to price regulation in the OECD area. Air travel, road freight and telecommunications - three areas in which Ukraine does not regulate prices - constitute three-quarters of the indicator. Retail distribution, where price regulation in Ukraine is relatively extensive, accounts for just one-quarter of the indicator score.

Figure A5. Price controls

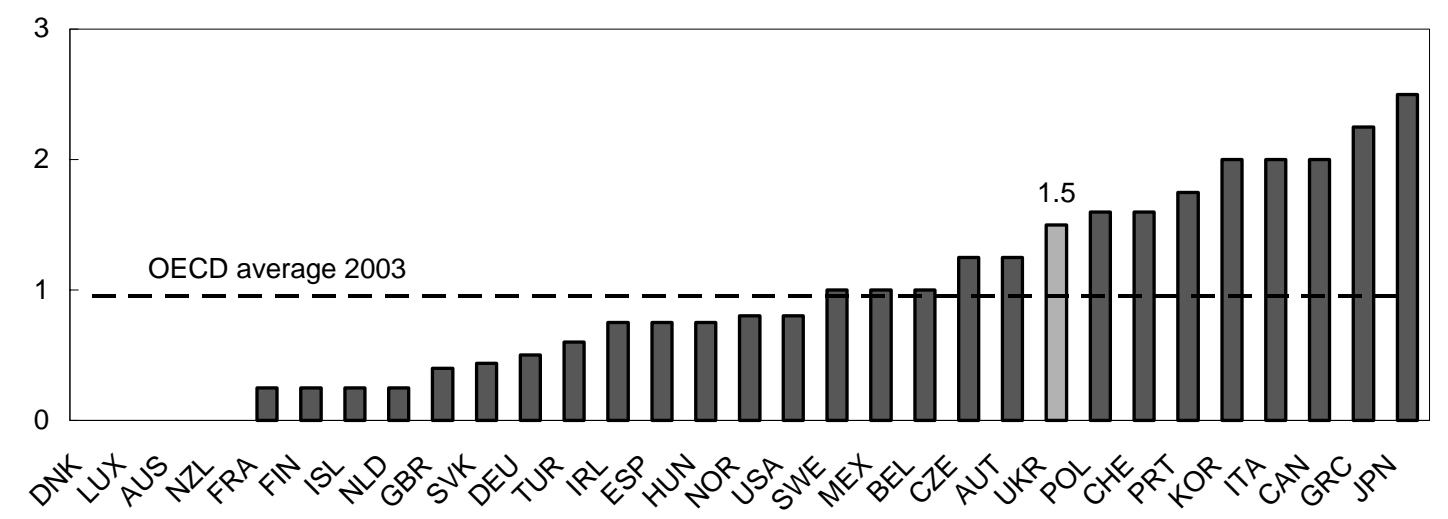


The command and control regulation indicator measures the extent to which the authorities use coercive (as opposed to incentive-based) regulation, both in general and in specific service sectors. Ukraine's rough average conceals a high degree of variation in the policy settings that underlie this indicator, which range from its very liberal policies vis-à-vis road freight and air travel, which are marketised sectors, to a much greater reliance on command and control in regulating the railways, which remain a vertically integrated state-owned monopoly.

Figure A6. Command and control regulation

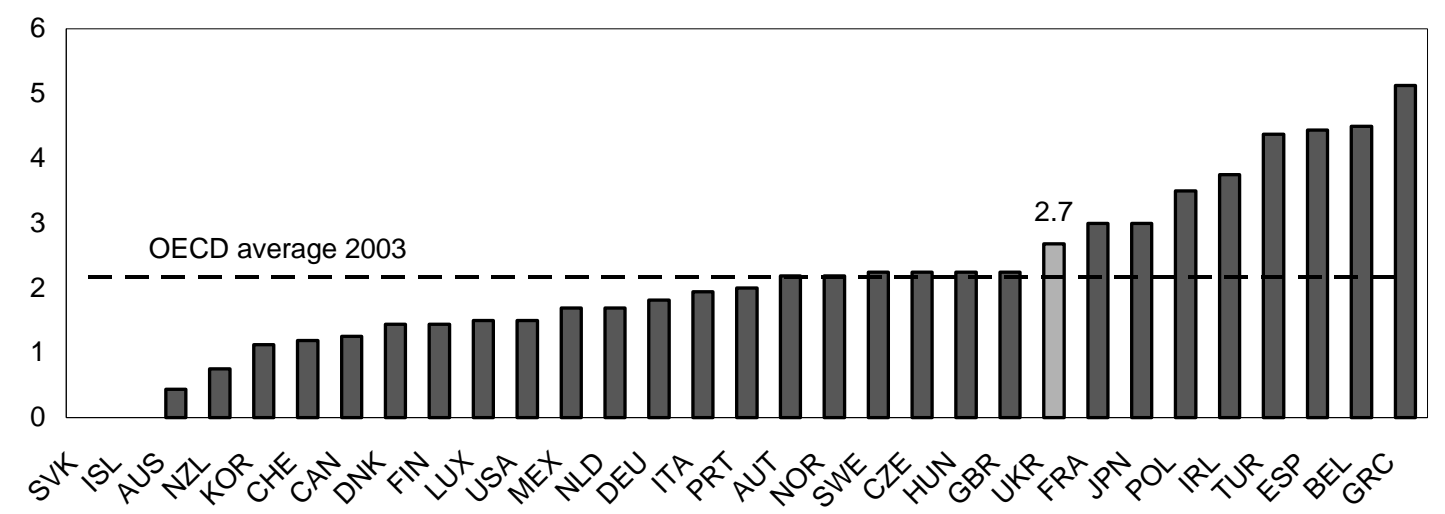

The licenses and permits indicator reflects the presence or absence of such devices as "one-stop shops" and "silence is consent" rules for getting information on, and issuing, licenses and permits. Ukraine's score reflects the heavy burden of licences and permits that remains even in the wake of the adoption of a new, more liberal law on the permit system in 2005.

Figure A7. Licenses and permits

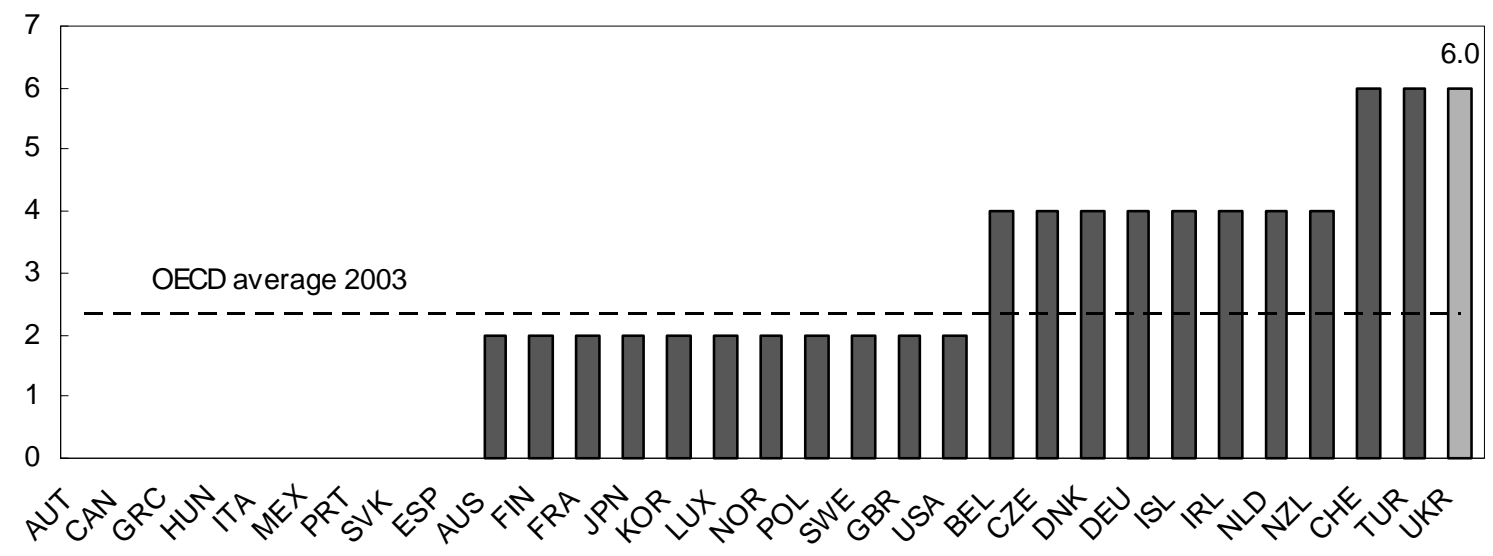


Communication and simplification of rules and procedures refers to aspects of the government's communication strategy and efforts to reduce/simplify the administrative burden of interacting with government. The reasons for Ukraine's poor performance on this indicator are discussed in the main text.

Figure A8. Communication and simplification

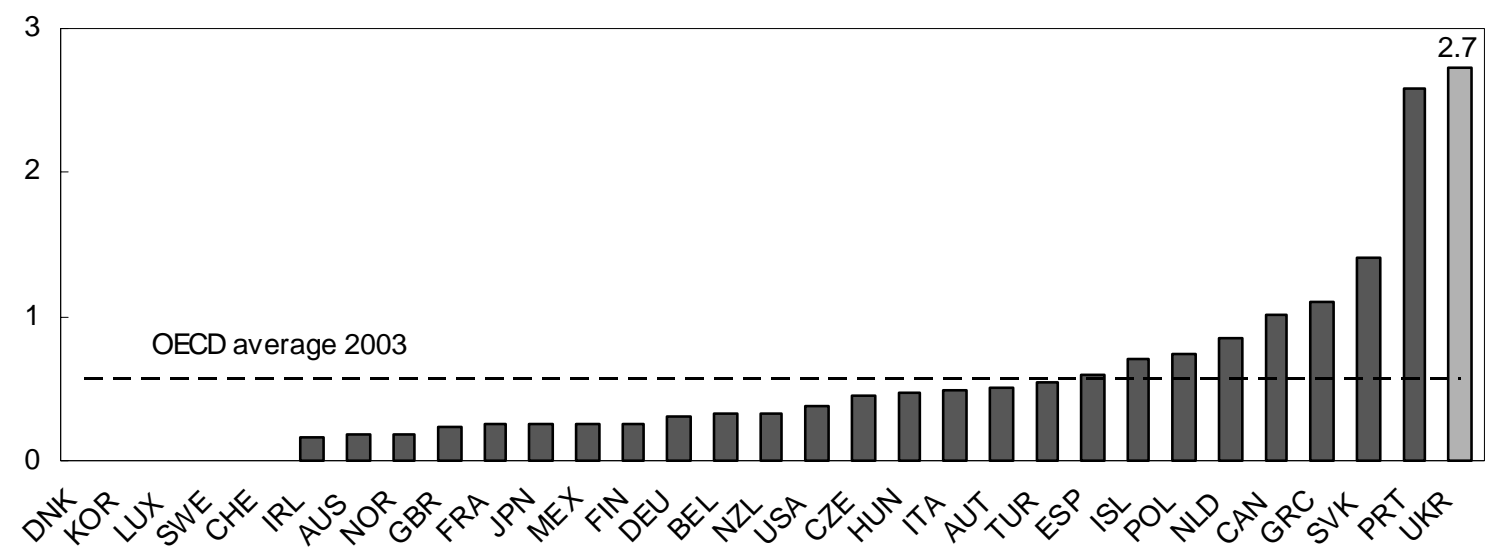

The start-up: corporations indicator reflects the number of mandatory procedures involved in the creation of new companies, as well as the number of agencies involved and the total cost of start-up procedures in both time and money. Costs have been converted at PPP exchange rates. ${ }^{3}$ Ukraine's indicator score reflects the substantial progress it has recently made in this area.

Figure A9. Start-up: corporations

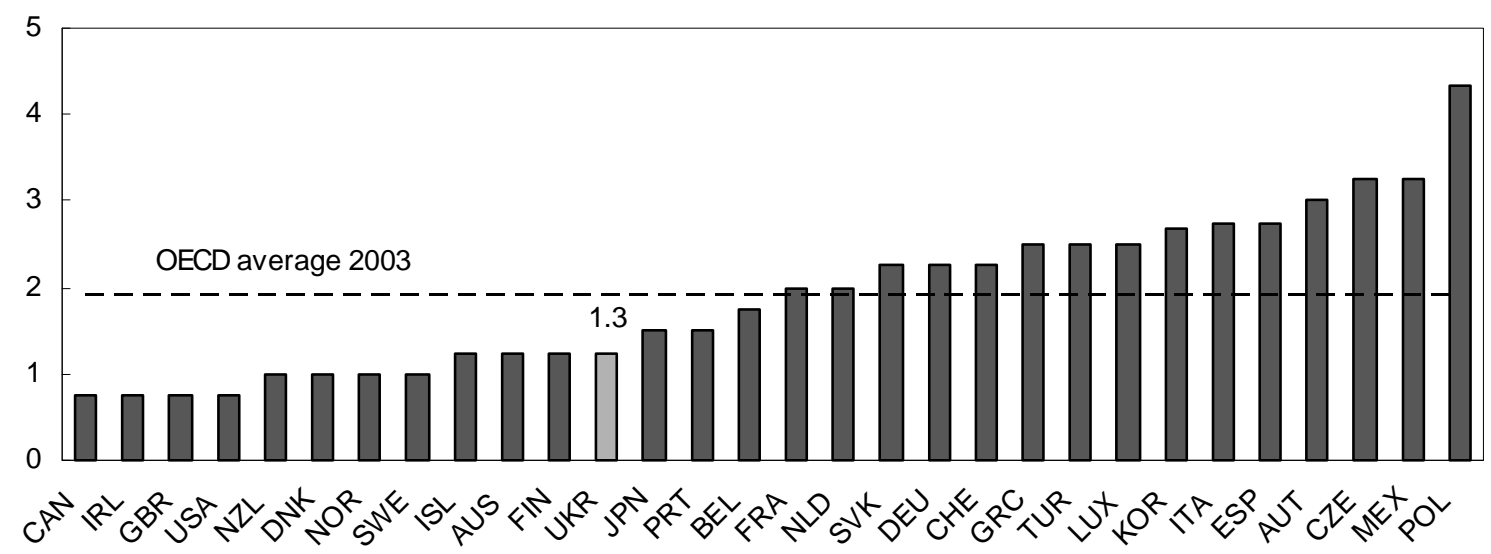

3. The results, therefore, differ from other published OECD assessments. Given the gap between the hryvnia's market exchange rate and purchasing-power parity, however, a meaningful comparison requires the use of PPP exchange rates for all countries. 
Start-ups: sole proprietors is constructed in a more or less identical fashion to the indicator for new companies but is concerned with unincorporated small businesses. Again, costs have been converted at PPP exchange rates. Here, too, Ukraine's score reflects recent improvements in the regulatory framework.

Figure A10. Start-up: sole proprietors

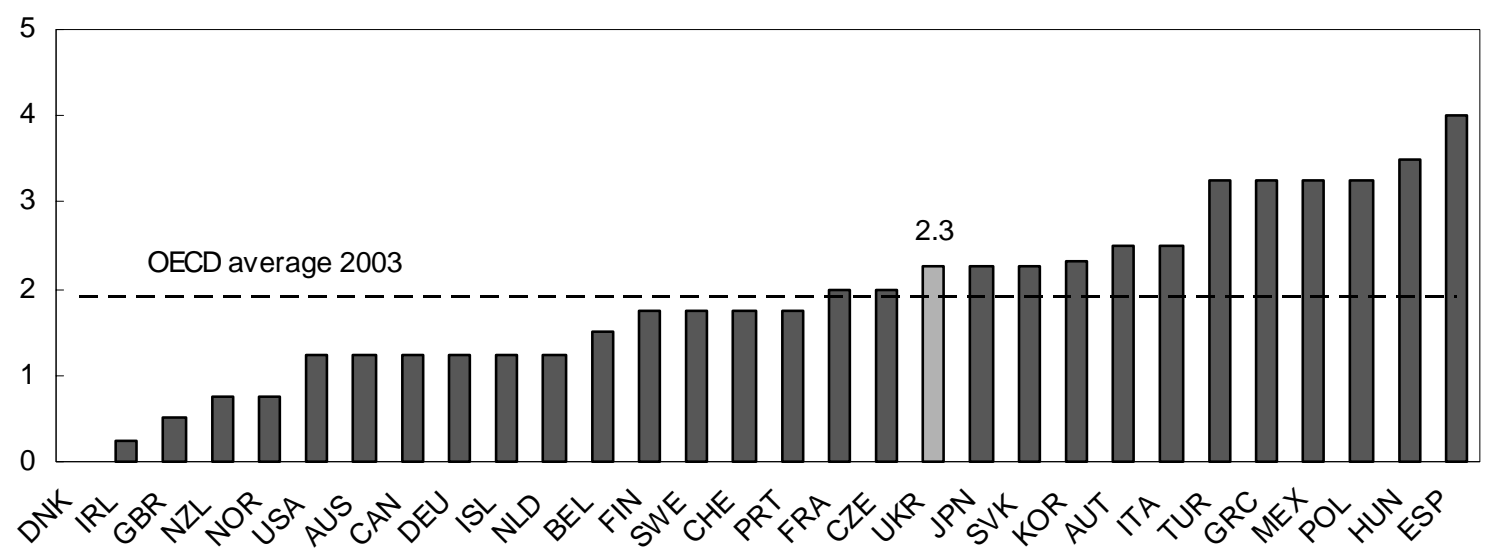

The sector-specific administrative burdens indicator reflects administrative burdens in the road transport and retail distribution sectors, two sectors that are commonly subject to rather heavy, competition-limiting regulation in OECD members. Ukraine scores just about the OECD average on regulation of retail distribution, but its policy settings in respect of road transport are exceptionally liberal.

Figure A11. Sector-specific administrative burdens

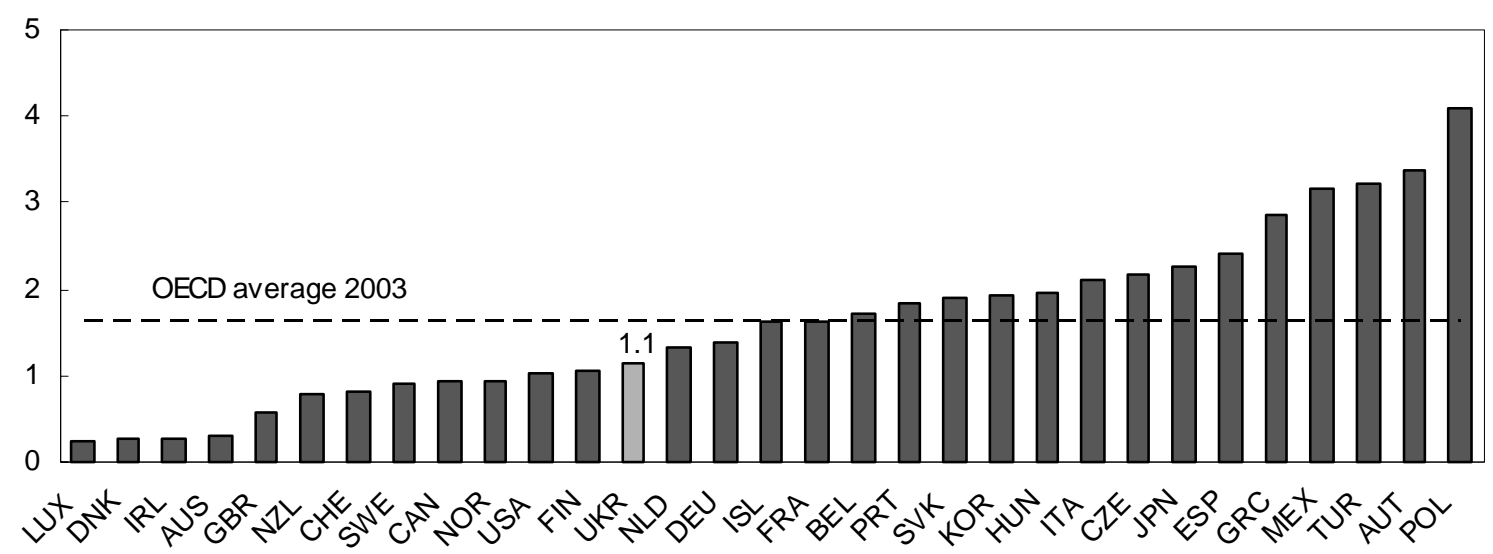


The legal barriers indicator refers specifically to the scope of explicit legal limitations on the number of competitors allowed in a wide range of business sectors or subsectors.

Figure A12. Legal barriers to entry

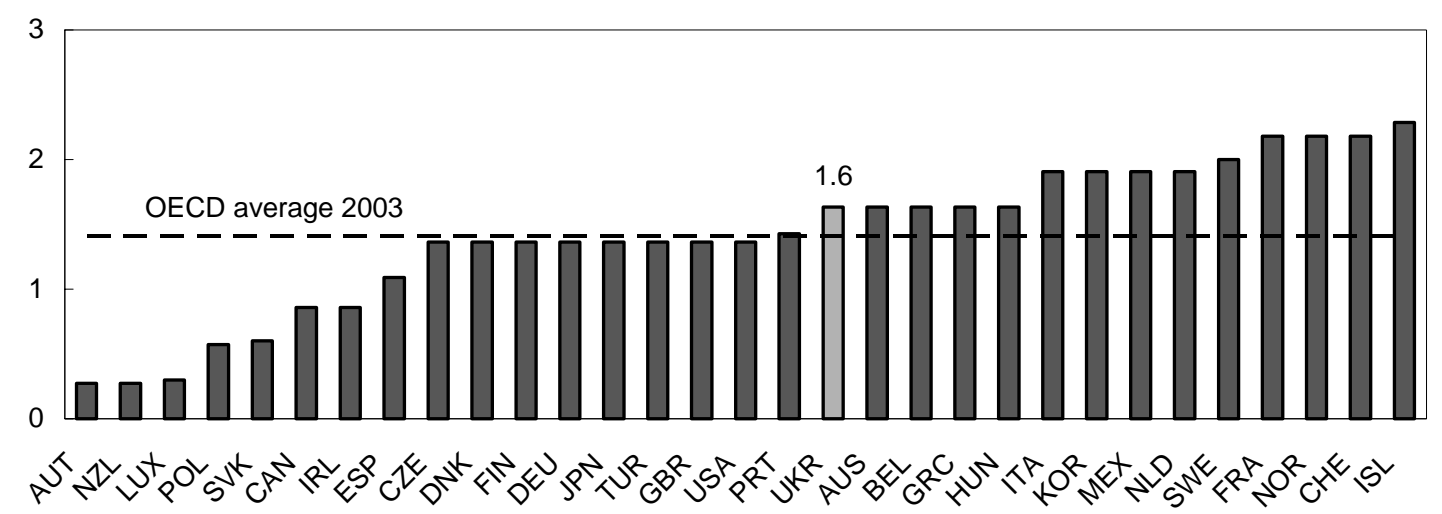

The indicator for antitrust exemptions measures the scope of exemptions to competition law that are either extended to public enterprises or authorised by government authority. In Ukraine's case, the above-average score simply reflects the power of the government to override decisions of the competition authority.

Figure A13. Antitrust exemptions

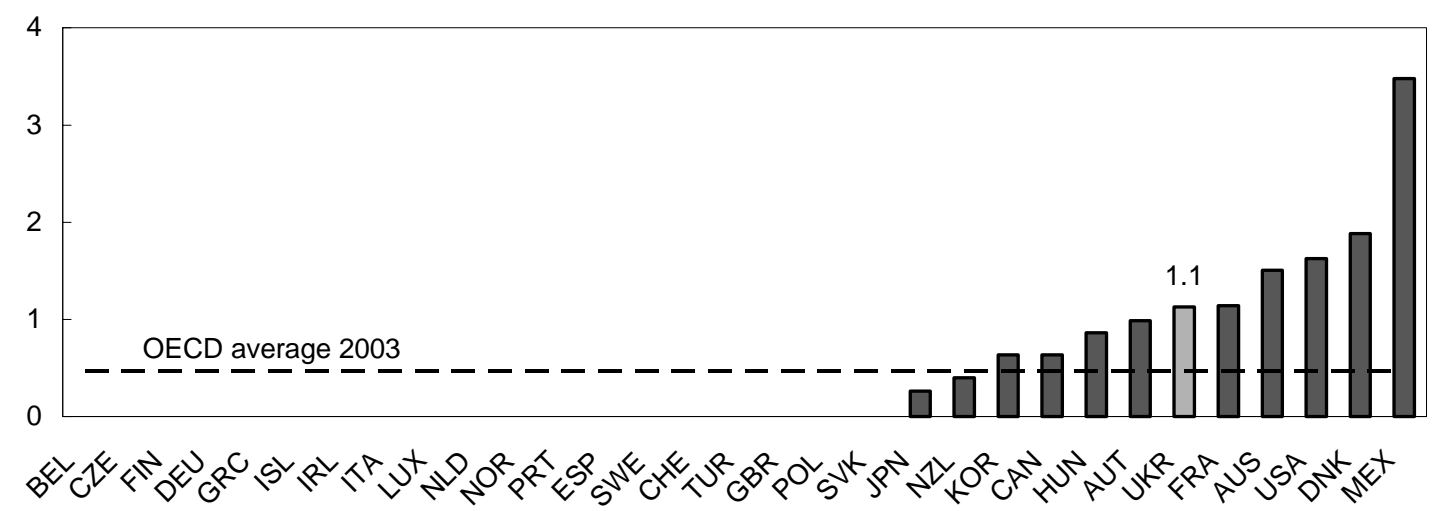


Ukraine ranks close to the OECD average on the ownership barriers indicator. Its score reflects legal restrictions on foreign acquisition of equity in public and private firms in the telecommunications and airlines sectors.

Figure A14. Barriers to foreign ownership

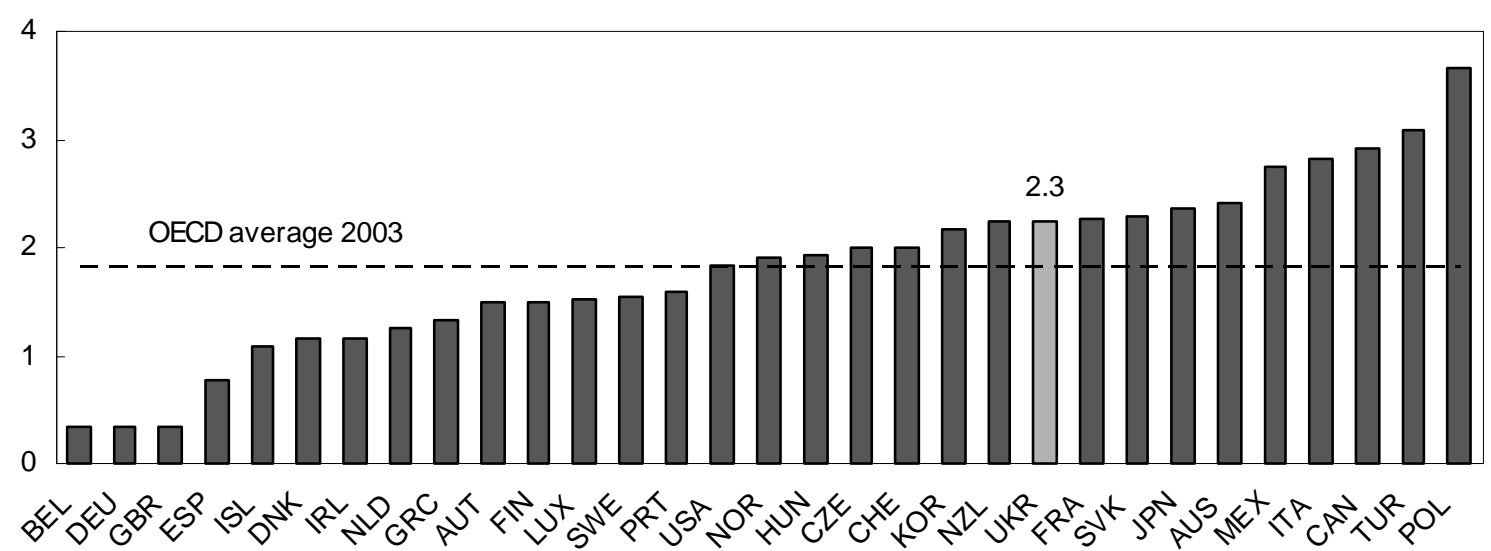

Tariffs reflects the (simple) average of a country's most-favoured-nation tariffs.

Figure A15. Tariffs

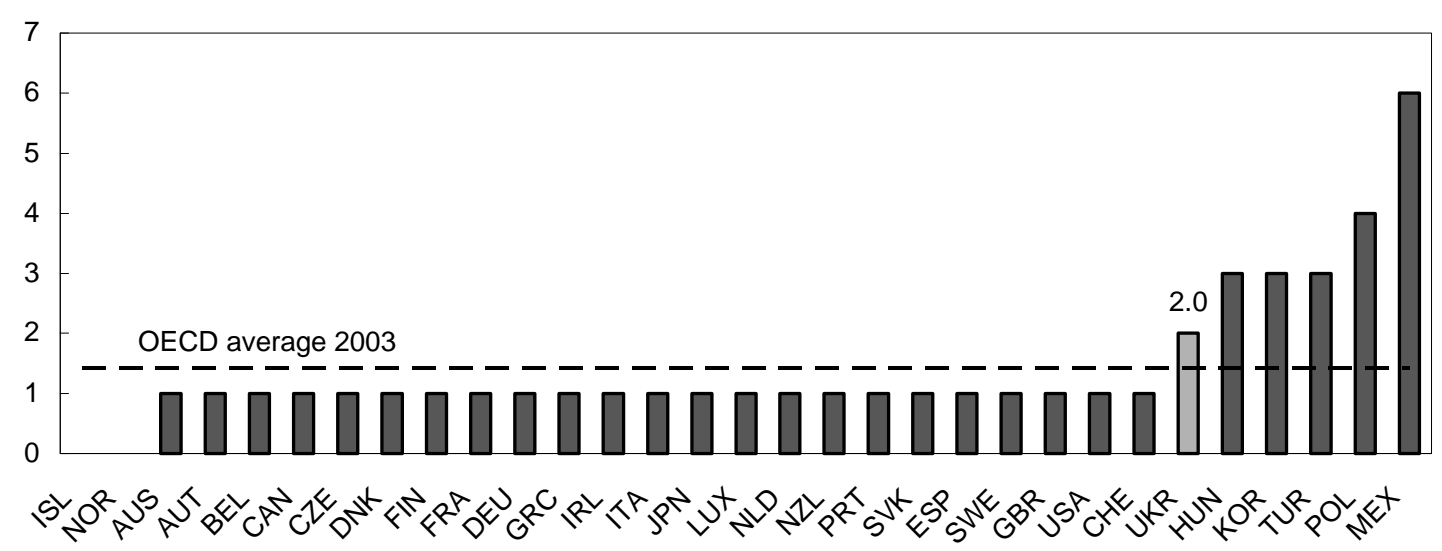


The discriminatory procedures indicator reflects the extent of discrimination against foreign firms at the procedural level. It does not cover restrictions on foreign ownership, which are captured by barriers to foreign ownership. In Ukraine's case, the high score reflects the failure to enshrine the principle of national treatment in legislation and the limited right of redress available to foreign companies.

Figure A16. Discriminatory procedures

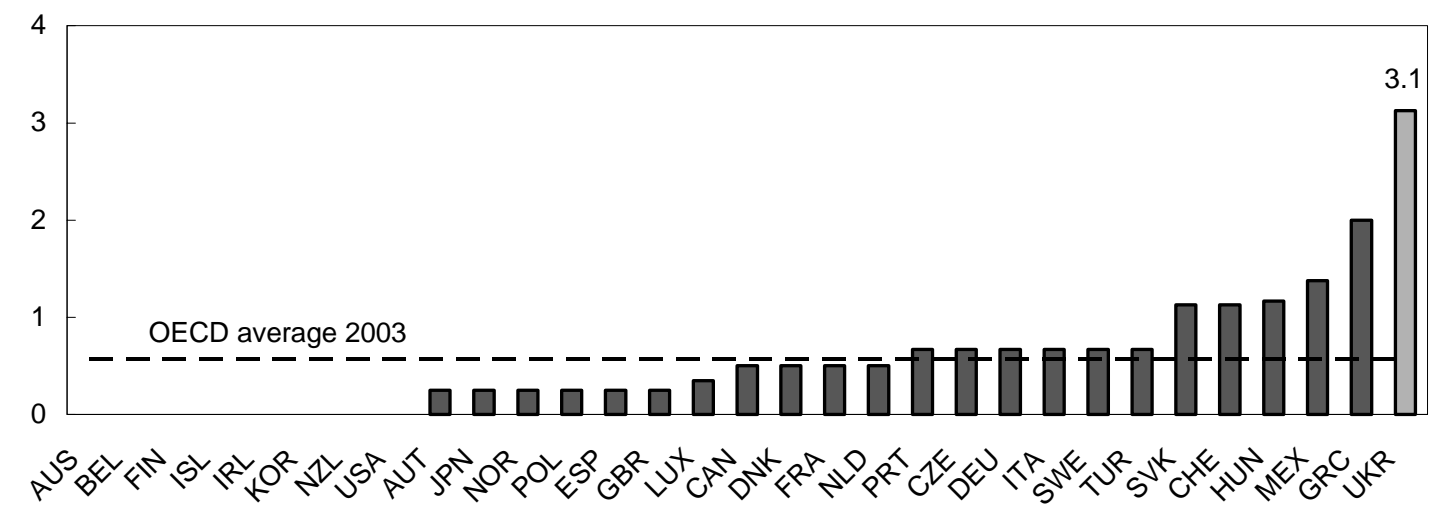

Finally, the indicator for regulatory barriers reflects other barriers to international trade, such as international harmonisation of standards and regulatory norms or mutual recognition agreements. Ukraine's very poor score on this indicator is a reflection of the lack of mutual recognition agreements with other countries and the absence of provisions encouraging regulators to use internationally harmonised standards and certification procedures.

Figure A17. Regulatory barriers to trade

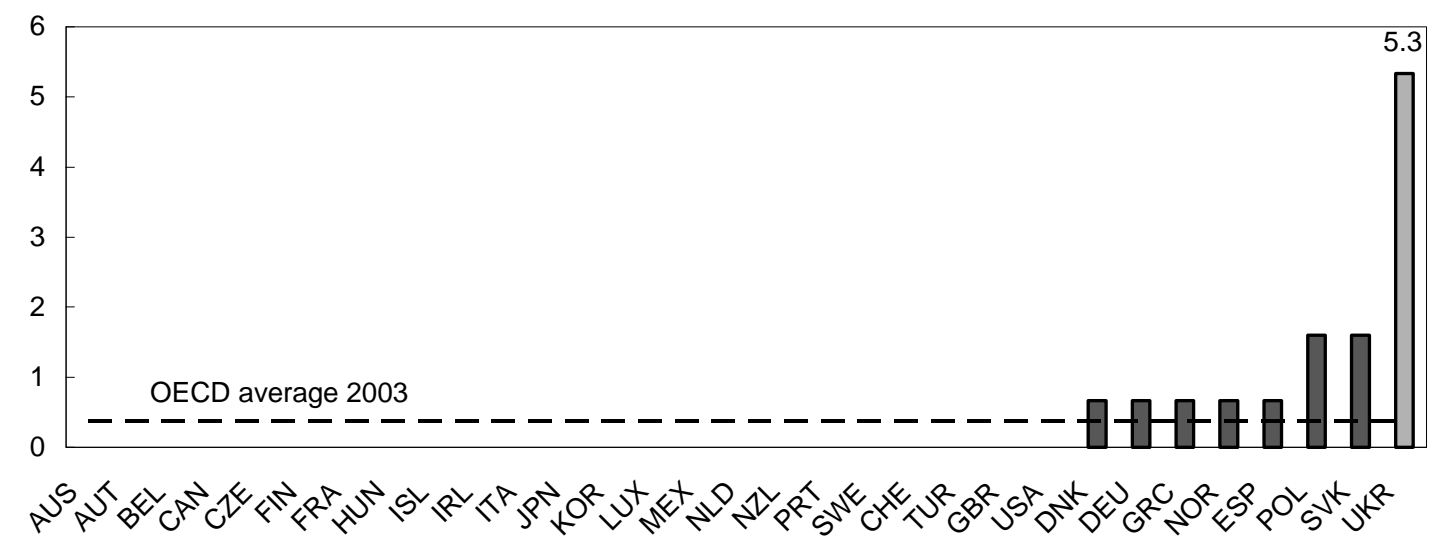




\section{ANNEX B}

\section{Labour productivity at firm level}

Table B1. Labour productivity difference between entry cohorts and old firms

\begin{tabular}{|c|c|c|c|c|c|c|c|}
\hline Sector & $\begin{array}{c}\text { Age } 0-2 \text {, } \\
\text { Exits by } \\
\text { age } 3\end{array}$ & $\begin{array}{c}\text { Age 0-2, } \\
\text { Too } \\
\text { early to } \\
\text { know }\end{array}$ & $\begin{array}{c}\text { Age 0-2, } \\
\text { Survives } \\
\text { to age } 3\end{array}$ & $\begin{array}{c}\text { Age 3-5, } \\
\text { Exits by } \\
\text { age } 6\end{array}$ & $\begin{array}{c}\text { Age 3-5, } \\
\text { Too } \\
\text { early to } \\
\text { know }\end{array}$ & $\begin{array}{l}\text { Age 3-5, } \\
\text { Survives } \\
\text { to age } 6\end{array}$ & $\begin{array}{l}\text { Age } 6 \\
\text { years }\end{array}$ \\
\hline Food and beverages & -44.5 & 0.3 & -7.5 & -41.1 & -21.1 & -6.3 & -32.8 \\
\hline Textiles & 75.2 & 46.2 & 75.8 & 35.5 & 54.9 & 48.9 & 10.8 \\
\hline Clothing and furs & 41.3 & 50.9 & 70.6 & 50.9 & 69.7 & 38.1 & 7.9 \\
\hline Leather and leather goods & 41.5 & 29.9 & 85.5 & 63.5 & 18.9 & 78.0 & 2.8 \\
\hline Wood and wood products & 118.9 & 107.8 & 116.1 & 55.0 & 86.2 & 44.1 & -8.4 \\
\hline Pulp and paper & 90.8 & 103.6 & 150.7 & 91.3 & 135.6 & 86.7 & 43.7 \\
\hline Publishing and printing & 123.8 & 117.9 & 119.9 & 29.1 & 123.9 & 91.0 & 63.2 \\
\hline Chemicals & 77.6 & 64.1 & 55.1 & 19.7 & 62.1 & 54.6 & 31.1 \\
\hline Rubber and plastics & 93.8 & 90.5 & 135.4 & 30.4 & 114.7 & 75.3 & 20.1 \\
\hline $\begin{array}{l}\text { Other non-metallic mineral } \\
\text { products }\end{array}$ & -10.5 & -21.0 & 31.0 & -4.4 & 11.8 & 11.5 & -21.7 \\
\hline Basic metals & -28.6 & -71.9 & -36.2 & -54.1 & -57.4 & 4.8 & -40.1 \\
\hline Fabricated metal products & 31.6 & 14.4 & 59.0 & 32.6 & 16.4 & 73.8 & 20.5 \\
\hline Machinery and equipment & 108.7 & 97.4 & 112.4 & 51.1 & 98.2 & 79.1 & 44.5 \\
\hline $\begin{array}{l}\text { Electrical machinery and } \\
\text { apparatus }\end{array}$ & 94.6 & 99.2 & 80.1 & 63.9 & 58.7 & 95.1 & 61.5 \\
\hline $\begin{array}{l}\text { Radio and TV equipment } \\
\text { and apparatus }\end{array}$ & 135.0 & 129.2 & 193.9 & 17.0 & 211.0 & 122.7 & 96.2 \\
\hline $\begin{array}{l}\text { Medical and optical } \\
\text { instruments, timepieces }\end{array}$ & 151.6 & 144.7 & 166.9 & 57.9 & 152.1 & 124.8 & 74.0 \\
\hline Motor vehicles and trailers & 30.3 & 30.4 & 75.6 & 114.1 & 40.3 & 40.3 & 22.7 \\
\hline Other transport equipment & -19.1 & 69.0 & 42.8 & 4.9 & 23.1 & 62.6 & 31.4 \\
\hline Average & 61.8 & 61.3 & 84.8 & 34.3 & 66.6 & 62.5 & 23.7 \\
\hline
\end{tabular}

Note: Each row contains a set of coefficients from an OLS regression also including year effects. They represent unweighted percent differences in labour productivity between each entry cohort and old firms. Old firms are those existing prior to the transition or ever having had some state ownership. The "too early to know" category is present because it is not known as of the last year covered in the dataset whether the firm survives to the particular age or not.

Source: Brown and Earle (2007a). 
Table B2. Labour productivity dispersion in Ukraine

\begin{tabular}{|c|c|c|c|c|c|c|c|c|c|c|}
\hline \multirow[b]{2}{*}{ Sector } & \multicolumn{2}{|c|}{1989} & \multicolumn{2}{|c|}{1992} & \multicolumn{2}{|c|}{1995} & \multicolumn{2}{|c|}{2000} & \multicolumn{2}{|c|}{2005} \\
\hline & SD & $10-90$ & SD & $10-90$ & SD & $10-90$ & SD & $10-90$ & SD & $10-90$ \\
\hline $\begin{array}{l}\text { Food and } \\
\text { beverages }\end{array}$ & 0.77 & 1.94 & 0.81 & 2.07 & 0.96 & 2.47 & 1.76 & 4.24 & 1.86 & 4.57 \\
\hline Textiles & 0.65 & 1.38 & 0.66 & 1.53 & 1.01 & 2.47 & 1.94 & 4.88 & 1.71 & 3.97 \\
\hline Clothing and furs & 0.54 & 1.36 & 0.45 & 1.12 & 0.99 & 2.39 & 1.72 & 4.21 & 1.46 & 3.53 \\
\hline $\begin{array}{l}\text { Leather and leather } \\
\text { goods }\end{array}$ & 0.29 & 0.79 & 0.57 & 1.25 & 1.02 & 2.69 & 2.05 & 5.15 & 1.79 & 4.32 \\
\hline $\begin{array}{l}\text { Wood and wood } \\
\text { products }\end{array}$ & 0.30 & 0.75 & 0.57 & 1.46 & 0.93 & 2.35 & 1.74 & 4.44 & 1.62 & 3.95 \\
\hline Pulp and paper & 0.43 & 1.10 & 0.70 & 1.79 & 1.19 & 2.69 & 1.84 & 4.46 & 1.67 & 3.93 \\
\hline $\begin{array}{l}\text { Publishing and } \\
\text { printing }\end{array}$ & 0.28 & 0.46 & 0.42 & 1.00 & 0.56 & 1.21 & 1.39 & 3.27 & 1.37 & 3.27 \\
\hline Chemicals & 0.61 & 1.62 & 0.76 & 1.80 & 1.01 & 2.34 & 1.69 & 4.22 & 1.55 & 3.82 \\
\hline Rubber and plastics & 0.51 & 1.36 & 0.78 & 2.01 & 1.06 & 2.64 & 1.75 & 4.29 & 1.56 & 3.78 \\
\hline $\begin{array}{l}\text { Other non-metallic } \\
\text { mineral products }\end{array}$ & 0.43 & 1.14 & 0.66 & 1.60 & 0.94 & 2.39 & 1.68 & 3.94 & 1.59 & 3.89 \\
\hline Basic metals & 0.59 & 1.58 & 1.06 & 2.71 & 1.34 & 3.85 & 2.04 & 4.83 & 1.88 & 4.60 \\
\hline $\begin{array}{l}\text { Fabricated metal } \\
\text { products }\end{array}$ & 0.41 & 0.88 & 0.75 & 1.86 & 1.02 & 2.56 & 1.72 & 4.24 & 1.54 & 3.77 \\
\hline $\begin{array}{l}\text { Machinery and } \\
\text { equipment }\end{array}$ & 0.37 & 0.95 & 0.62 & 1.54 & 0.86 & 2.07 & 1.68 & 4.18 & 1.55 & 3.63 \\
\hline $\begin{array}{l}\text { Electrical } \\
\text { machinery and } \\
\text { apparatus }\end{array}$ & 0.52 & 1.27 & 0.79 & 1.91 & 1.19 & 3.03 & 1.79 & 4.50 & 1.56 & 3.88 \\
\hline $\begin{array}{l}\text { Radio and TV } \\
\text { equipment and } \\
\text { apparatus }\end{array}$ & 0.36 & 1.07 & 0.68 & 1.67 & 0.89 & 2.28 & 2.24 & 5.54 & 1.96 & 4.80 \\
\hline $\begin{array}{l}\text { Medical and optical } \\
\text { instruments, } \\
\text { timepieces }\end{array}$ & 0.37 & 0.87 & 0.49 & 1.23 & 0.95 & 2.20 & 1.92 & 4.56 & 1.87 & 4.62 \\
\hline $\begin{array}{l}\text { Motor vehicles and } \\
\text { trailers }\end{array}$ & 0.33 & 0.74 & 0.57 & 1.67 & 0.86 & 2.47 & 1.59 & 4.17 & 1.72 & 4.39 \\
\hline $\begin{array}{l}\text { Other transport } \\
\text { equipment }\end{array}$ & 0.34 & 1.00 & 0.65 & 1.61 & 0.80 & 2.18 & 1.77 & 4.03 & 1.76 & 3.88 \\
\hline Average & 0.45 & 1.12 & 0.67 & 1.66 & 0.98 & 2.46 & 1.79 & 4.40 & 1.67 & 4.03 \\
\hline
\end{tabular}

Note: SD refers to standard deviation of labour productivity, and 10-90 refers to the percentage difference in labour productivity between the firm at the 90th percentile in the distribution and the firm at the 10th percentile.

Source: Brown and Earle (2007a). 
ECO/WKP(2007)34

\section{ANNEX C \\ Competition and productivity dynamics at the firm level}

This annex presents a brief overview of the methodology used to assess the impact of greater competition on labour productivity at firm level.

\section{Data}

The database has been drawn from the official register of industrial enterprises for 2000-05 and contains 350000 observations. After elimination of observations with missing data or extreme values - as well as observations which correspond for a given year to a migration of a firm from one sector to another - the dataset contains around 180000 observations, 155000 in industry and 25000 in market services (transport, telecommunications, wholesale and retail trade, hotels and restaurants, business services, real estate and finance). In the absence of reliable measures of the capital stock, the productivity variable used in the regressions is labour productivity and not total factor productivity. The real growth of labour productivity is estimated using sales volumes, total employment and, as a deflator, the producer price index at a two-digit level. The NACE classification code is used as the basis for computing Herfindahl- Hirschmann Indexes (HHIs) at five-digit level. The database was supplemented with data on imports and exports at six-digit level of the HS6 classification, converted into ISIC with standard matrix tables. ${ }^{78}$ Export-oriented sectors are defined as those for which the share of exports exceeds $30 \%$ of sales. The same threshold is used for import-competing industries (these conditions are not mutually exclusive).

\section{The empirical model}

The effect of the degree of concentration and of the technology gap between industrial firms on their efficiency gains is estimated according to the following specification:

$$
\Delta R L P_{i, t+1}=\beta_{1} H H I_{j, t}+\beta_{2}\left(D_{i s t_{i, t}}\right) \times H H I_{j, t}+\beta_{3}\left(D_{i s t_{i, t}}\right)+X_{i, t} \gamma+v_{t+1}+u_{i}+\varepsilon_{i, t+1}
$$

where $\triangle \mathrm{RLP}_{i t}$ is the real labour productivity growth of firm (i) in sector (j) at date (t); $H H_{j t}$ is the Herfindahl-Hirschman Index of industry $j$, calculated at the regional level; $\left(\right.$ Dist $\left._{i t}\right)$ is the firm's distance to the production possibility frontier in sector $(\mathrm{j})$; and $X_{i t}$ is a vector of firms and industry characteristics (essentially the level of employment and the import penetration ratio). Concerning the error components, $v_{t+l}$ are time dummies; $u_{i}$ are firm-specific effects; and $\varepsilon_{i t+l}$ is an error term assumed to be uncorrelated through time (typically, "white noise"). Fixed assets, when available, were also included as a control variable to check the robustness of the results: its inclusion did not alter significantly the order of magnitude of the coefficients. ${ }^{79}$

78. More details on the construction of the data set are available on request.

79. The coefficient for HHI was only slightly lower. 


\section{WORKING PAPERS}

The full series of Economics Department Working Papers can be consulted at www.oecd.org/eco/Working_Papers/

574. Too little destruction too little creation: A Schumpeterian diagnosis of barriers to sustained growth in Ukraine

(September 2007) Christian Gianella and William Tompson

573. How do the OECD Growth Projections for the G7 Economies Perform? A post-mortem. (September 2007) Lukas Vogel

572. Austria's deepening economic integration with Central and Eastern Europe (August 2007) Rina Bhattacharya

571. Meeting the challenges of decentralization in France (July 2007) Stéphanie Jamet

Faire face aux défis de la décentralisation en France (juillet 2007) Stéphanie Jamet

570. Enhancing incentives to improve performance in the education system in France (July 2007) Paul O’Brien

Renforcer les incitations à une meilleure performance du système éducatif en France (juillet 2007) Paul O’Brien

569. Combating poverty and social exclusion in France (July 2007) Stéphanie Jamet

Lutter contre la pauvreté et l'exclusion social en France (juillet 2007) Stéphanie Jamet

568 The competition law and policy indicator (July 2007) Jens Hoj

567. Structural policies and economic resilience to shocks (July 2007) Romain Duval, Jørgen Elmeskov and Lukas Vogel

566. Family policy in Hungary: how to improve the reconciliation between work and family? (July 2007) Philip Hemmings

565. Encouraging sub-national government efficiency in Hungary (July 2007) Alessandro Goglio

564. Integration of immigrants in OECD countries: do policies matter? (July 2007) Orsetta Causa and Sébastien Jean

563. The unemployment impact of immigration in OECD countries (July 2007) Sébastien Jean and Miguel Jiménez

562. Migration in OECD countries: labour market impact and integration issues (July 2007) Sébastien Jean, Orsetta Causa, Miguel Jiminez and Isabelle Wanner

561. The internationalisation of production, international outsourcing and employment in the OECD (June 2007) Margit Molnar, Nigel Pain and Daria Taglioni

560. Why has Swedish inflation been persistently low? (June 2007) Felix Hüefner 
559. The Swedish housing market - better allocation via less regulation

(June 2007) Felix Hüefner and Jens Lundsgaard

558 Linkages between performance and institutions in the primary and secondary education sector (June 2007) Douglas Sutherland and Robert Price

557. Toward a more efficient taxation system in New Zealand (June 2007) Annabelle Mourougane

556. Income inequality, poverty and social spending in Japan (June 2007) Randall Jones

555. Improving the efficiency of health care spending: selected evidence on hospital performance (May 2007) Espen Erlandsen

554. Cross-country analysis of efficiency in OECD health care sectors: options for research (May 2007) Unto Häkkinen and Isabelle Joumard

553. What promotes fiscal consolidation: OECD country experience

(May 2007) Stéphanie Guichard, Mike Kennedy, Echkard Wurzel and Christophe André

552. Globalisation and the macroeconomic policy environment

(April 2007) Karine Hervé, Isabell Koske, Nigel Pain, Franck Sédillot

551. Why has core inflation remained so muted in the face of the oil shock?

(April 2007) Paul van den Noord and Christophe André

550. Housing markets and adjustments in monetary union (April 2007) Peter Hoeller and David Rae

549. Financial markets in Iceland (March 2007) Peter Tulip

548. The political economy of delaying fiscal consolidation (March 2007) Boris Cournède

547. The impact on growth of higher efficiency of public spending on schools (March 2007) Frédéric Gonand

546. Performance indicators for public spending efficiency in primary and secondary education (February 2007) Douglas Sutherland, Robert Price, Isabelle Joumard and Chantal Nicq

545. Monetary policy and macroeconomic stability in Latin America: the cases of Brazil, Chile, Colombia and Mexico

(February 2007) Luiz de Mello and Diego Moccero

544. The Brazilian "tax war": the case of value-added tax competition among the states (February 2007) Luiz de Mello

543. Public spending efficiency: institutional indicators in primary and secondary education (January 2007) Frédéric Gonand, Isabelle Joumard and Robert Price

542. Enhancing turkey's growth prospects by improving formal sector business conditions (January 2007) Rauf Gönenç, Willi Leibfritz, Gökhan Yilmaz 